\title{
C.9.
}

HWHE WOHRT LIWING A PURSONAL FXPERIENCE

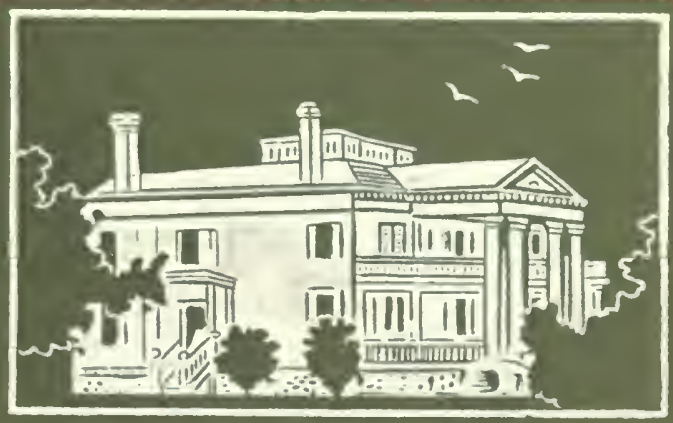

'PHOMAS DIXON JR 


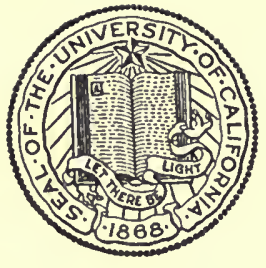

\section{THE LIBRARY OF}

THE UNIVERSITY OF CALIFORNIA LOS ANGELES 
DIXoN, Thomas, novelist, playwrlght; $b$.

Shelby, N.C., Jan. 11, 1864; 8. Kev. Thomas and Amanda Elizabetis (McAfee) D.: brother of AmzI Clarence D. (q.v.); A.M., Wake liorest Coll.; N.C., 1883; LL. B. Greensboro (N.C.) Law Sch., 1886; admitted to bar all courts, N.C. and U.S. Llst. and Supreme cts., 1886 ; scholarshlp, history and polItic8, Johns Hopkins, 1883-4; $m$. Harriet Bussey, of Columbus, Ga., Nar. 3, 1856. Mem. N.C. leglslature, is55-6; reslgned to enter Bapt. minlstry, Oct., 1886; pastor Ral. elgh, N.C., 1887, Boston, 1888.9, New York, 1859. 99; popular lyceum lecturer, 1859-1903. Demo. crat. Clubs: Players, Lambs, Friars. A uthor: l,eopard's Spots, 1902; The One Woman, 1903; The Clansman, 1905; The Llfe Worth Living, 1905: The Traitor, 1907; Comrades, 1909: The Root of ErII, 1911; The Slns of the Father, 1912; The Southerner, 1913; The VIctIm, 1914; Foolish Virgin, 1915; The Birth of a Nation (photoplay), 1915; Fall of a Nation, 1916; The IVay of a Mian, 1918; A Man of the l'eople, 1920; The Man in Gray, 1921. Home: S67 IRiverside Drive, New York; (ucinter) Munden, Va. 



\section{Digitized by the Internet Archive in 2007 with funding from Microsoft Corporation}







THE LIFE WORTH LIVING 


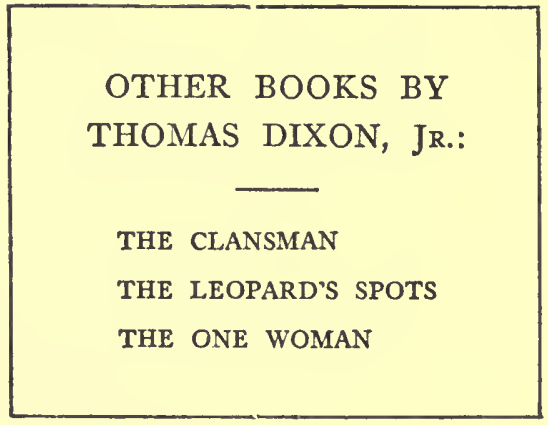





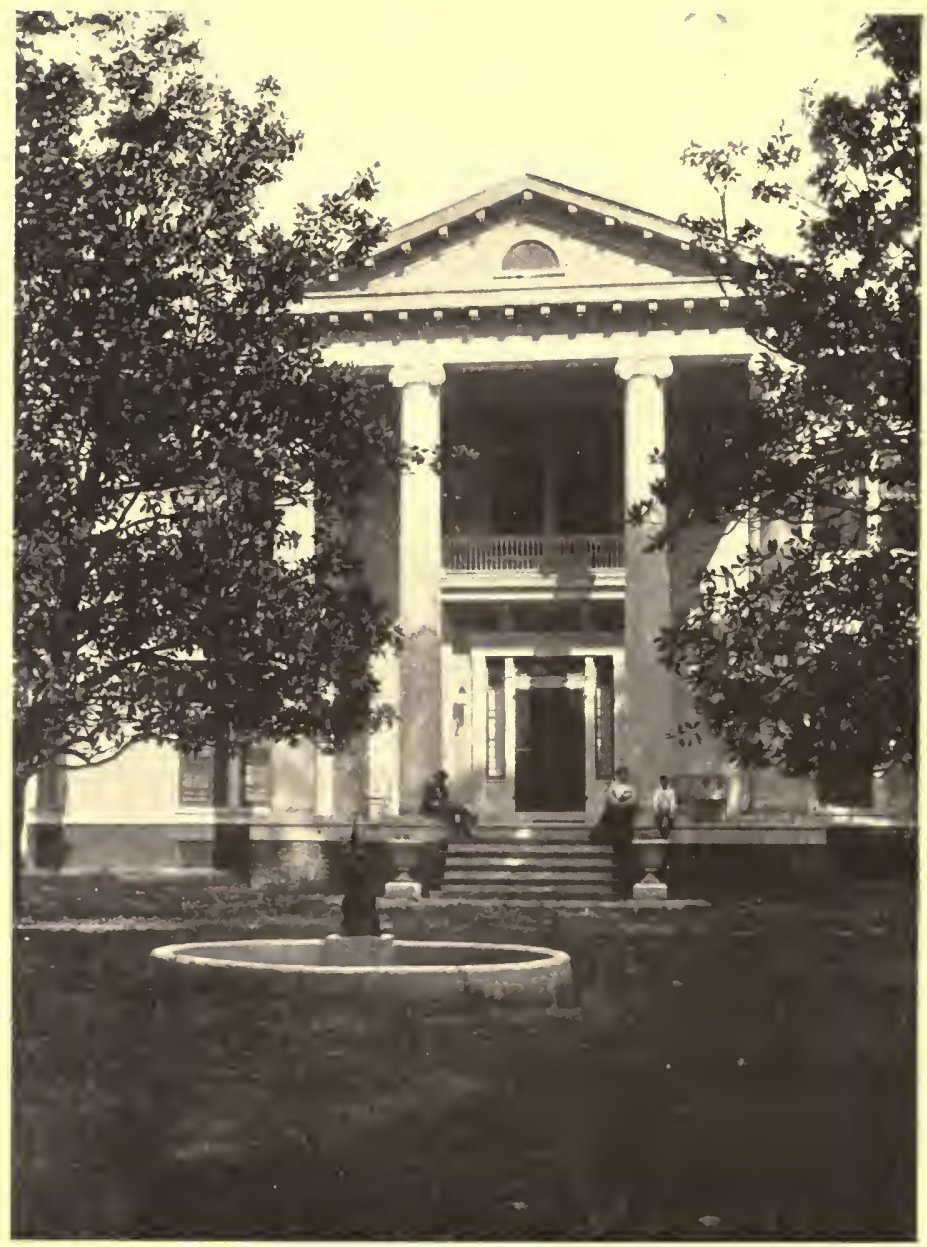

"ONE GREAT PASSION OF MY LIFE WAS THE DREAM OF A BEAUTIFUL HOME" 


\title{
The \\ LIFE WORTH LIVING \\ $A$ Personal Experience
}

\section{By \\ THOMAS DIXON, JR.}

Author of "The Leopard's Spots," "The Clansman," Etc.

Illustrated with photographs by the Autbor

\author{
Garden City New York \\ DOUBLEDAY, PAGE \& COMPANY \\ IgIO
}


Copyright, 1905, by

Thomas Dixon, Jr.

Published, May, rgos

All rights reserved, including that of translation into foreign languages, including the Scandinavian. 
S521
D64l

TO

Jorban and Thomas

MY SONS AND COMRADES

IN THE LIFE WORTH LIVING 



\section{CONTENTS}

CHAPTEK

PAGI

I. Dreams and Disillusion . . .

II. In Old Tidewater Virginia . $\quad$ - 8

III. Beside Beautiful Waters . • . 16

IV. The Music of the Seasons - . 23

V. The Fellowship of Dogs • • • 29

VI. Some Sins of Nature . . . 4 4I

VII. The Shouts of Children . . . 52

VIII. First Lessons in Life $\quad$ - . 64

IX. Along Shining Shores . . $\quad 7^{2}$

X. The Breath of the Southern Seas . $\quad \delta_{9}$

XI. In the Haunts of Wild Fowl • . 107

XII. The Frozen Fountain . . . $\quad r_{30}$

XIII. The City's Lambent Flame • • 135

XIV. What is Life? • • • • • 137 



\section{LIST OF ILLUSTRATIONS}

"One great passion of my life was the dream of

a beautiful home" . . .

Fromtispiece TACING PAGE

"Just a nineteen-foot slit in a block of scorched mud with a brownstone veneer" . . 6 "A stately Colonial home two hundred years old" 8 "The Old Dominion steamer has an artistic little pier on the upper end of the lawn" . . Io "In the high hills rise cool streams of fresh water to turn our mill-wheels" . . I 2 "Its great hall" • • • • • • • . I4 "The grass of the lawn rolls sheer into the dead line of the salt tide" . . . . I6 A friend from the barn . . . . 18 "The oaks and elms I love best" . . . 20 "Through the shadows of the trees the waters gleam" . . . . . . . - 22 The author at work in his cabin . . . . 24 "The drives in summer along the country roads are of surprising beauty" . . . 26 "The lawn is never quite bare" . . . 28 "The dog is the most faithful, the most lovable, the most companionable of all the animals that associate with man" . . . - 30 ix 


\section{LIST OF ILLUSTRATIONS-Continued}

FACING PAGE

Bob on a close point . . - . - $\quad 32$

The log-cabin study on the edge of the lawn 34 Sailor and the boys in private theatricals-

"The Mystery of Sleep" . . . . 38

The inevitable . - . . . - 48

"We have a beautifully curved sand beach on the

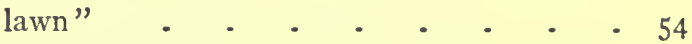

"All have saddles and ride like veteran cavalrymen" . . . . . . . 56

"Another pleasure of my boys is the work of the trapper" - . - . . . 58

"I believe in the gun for a normal boy" . . 60 "The first man was a hunter" . . . . 62 "He learns that winds and tides have souls" 66 "Away over the endless marsh" . . . 78 "Place our decoys on the edge of the receding surf" . . . . . . . . 86 "Sometimes the sky is black with them" . 88 The Dixie . . . . . . . . 102 "I never knew how much beautiful weather there

was in winter" . . . . . . ro8 "George and I crouched among them" . . I 24 "We are homeward bound now, with her big yacht ensign set aft and her colours at her masthead" . . . . . . . 128 "The ermine robe of the North" . . . I30 
THE LIFE WORTH LIVING 



\section{The Life Worth Living}

\section{CHAPTER I}

\section{Dreams and Disillusion}

Whether life is really worth living depends largely on where you try to live it.

The one great passion of my life was the dream of a beautiful home. This homedream crept slowly into the soul long before the face of a woman came to smile at all other hopes and fears. It required no pleading to make her feel its beauty. She, too, had seen it in a vision long ago. Then tiny baby feet came trooping into a cottage before the money was in the bank to build this dream.

Another passion of my boyhood was the 
hope of life in a great city. From the distance of the farm this vision was radiant with the splendours of wealth and power. I dreamed of its boulevards, its parks, its palatial homes, and its gleaming lights. The lambent flame of its distant life filled the horizon with the glory of an endless sunrise.

So in the natural course of events New. York swept us into its seething tide.

We struggled bravely to save both these dreams. First we rented a modest little slitin-a-wall fourteen feet wide, far uptown, for which we paid one thousand dollars to the landlord annually, and five hundred, more or less, to the elevated road for the right to be jabbed in the ribs while we held to a strap to get there.

Then we tried a nice "airy apartment" downtown. It had six "rooms." One opened on the street, four looked down into a dark well, and the kitchen opened on an iron grillwork that gave it the appearance 


\section{Dreams and Disillusion}

of a jail. The children were omnipotent and omnipresent. By the record in the family Bible we had only three. But they managed to get into every room in that flat at the same minute, and their name was legion.

We tried boarding with a nice old lady who had an eye that could chill the most turbulent child into silence. Our little girl took pneumonia, and we had two doctors and two trained nurses in that boarding house for six weeks.

Then the suburban home. We bought a vacant lot, with a waterfront of sixty feet, at Bensonhurst, and built on it. When finished it cost sixteen thousand dollars, and it took most of the time of one man to keep the tin cans, driftwood, dead cats and dogs off that sixty feet of waterfront.

The first time I tried to go home on Sunday, I got jammed in a cheerful crowd that started to Coney Island by way of Benson- 
hurst, gave it up after two hours, and didn't go home till morning. The first big snowstorm that came in the winter buried the trolley lines, and I didn't see my wife and children for two days. As the telephone wires were down I could only hope for the best. I sold the place to a bigger fool, after a patient search of four weeks for him. The ease with which I got out of that house, with only the loss of the carpets and window shades, I shall always regard as a mark of the special favour of God.

I bought a five-acre place on Staten Island on the top of the highest hill. It had a grand view of the sea, Sandy Hook and the shipping. The mosquitoes were so thick, so enormous, and so venomous, that they could attack and kill a horse if left to their mercy. Their fang was so poisonous that when they bit one of our boys his little legs and arms would swell as though a snake had struck him; and at the end of the summer he 
drooped into a deadly malarial fever from which we barely saved him alive, but with both legs paralyzed for life. With the shadow of this sorrow darkening the world, we sold the place to the first bidder, and tearfully returned to the city.

By this time we were convinced that the only way to really live in New York was to buy a decent home near Central Park, whatever the cost, and settle for life. We found it after a search of two months. It was located on West Ninety-fourth Street, within the block facing the park.

We had a delightful time spending a thousand dollars decorating it to our own taste. It was a neat brownstone front, nineteen feet wide, in a solid block of similar houses. It had a high stoop, iron bars on the basement windows through which we looked from the dining table, and a kitchen behind this dining-room opening into the paved cat-yard $19 \times 20$. The floor above contained a narrow 
hall, parlour and library. The next story had two bedrooms and a bathroom, and the top floor had two "large" rooms and two small ones inside. The wood was hard, the mantels and chandeliers pretty, the fireplaces poetic looking, with iron logs to imitate wood, and it cost us twenty-five thousand dollars.

The taxes, insurance and repairs still held a fixed charge on the place of about $\$ 35^{\circ}$ annually. A house in New York is the easiest thing a tax-gatherer has to manage. Only one man in ten ever dares to own one. The others keep moving.

Within six months this dream had faded.

Our home was just a nineteen-foot slit in a block of scorched mud with a brownstone veneer in front. Our children were penned in its narrow prison walls through the long winters, and forbidden to walk on the grass in the cold, dreary spring. The doctor came to see us every week. 


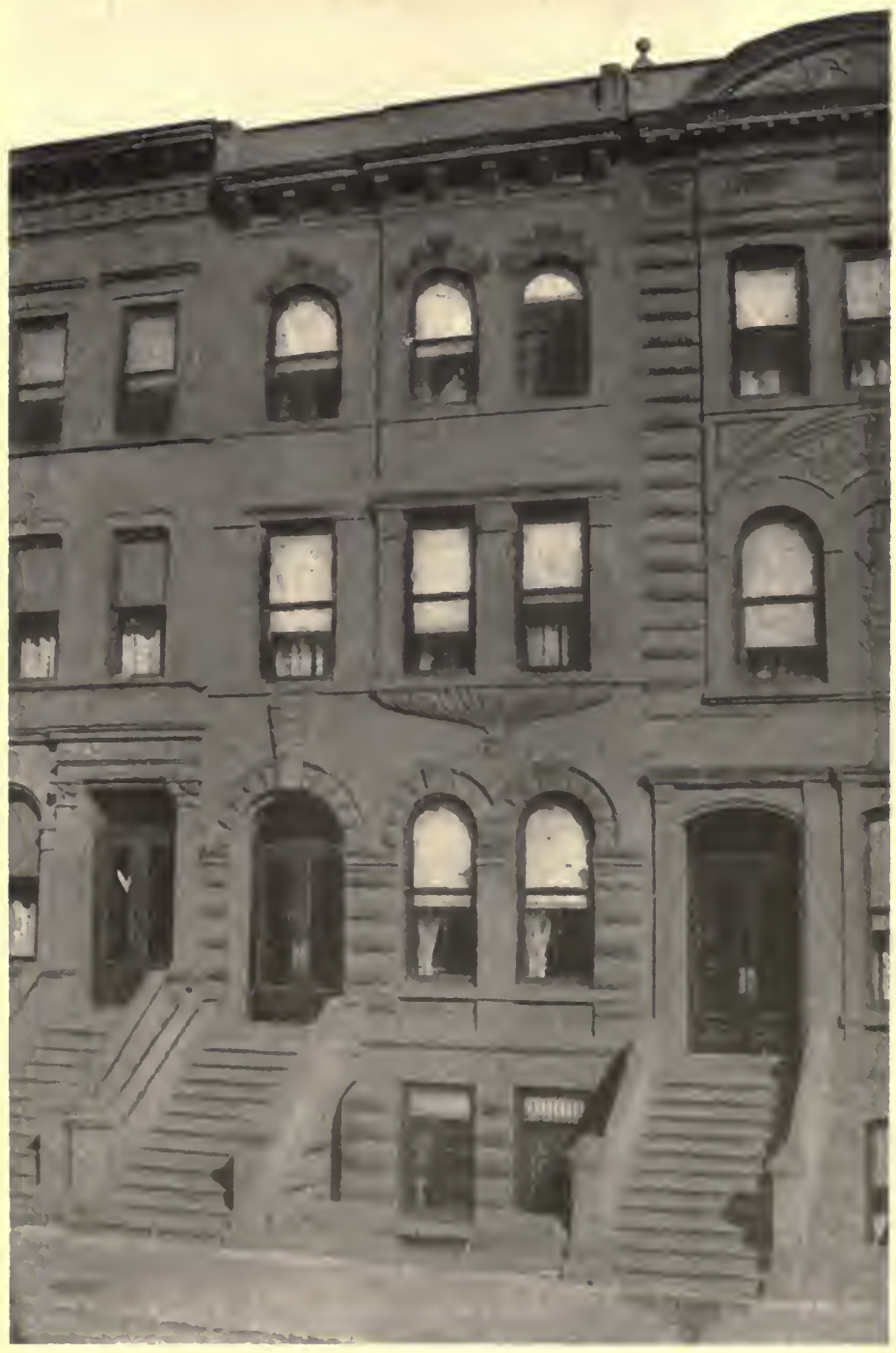

"JUST A NINETEEN-FOOT SI.IT IN A BIOCK ()F SCORCHFI MUD WITI A IBROWNSTONF: VINEER" 

The disillusioning was complete. We had stayed in New York eleven years, moved twelve times, worn out three sets of household goods, and aided in the revival of the carpet trade, before we found out what ailed us.

At last we knew that the stamping-ground of the great herd might be a good place for trade, but that God never meant for man to build a home and rear children in it.

And then the longing for the country life in which we had both been reared came over us with resistless power. The smell of green fields and wild flowers, the breath of the open sea, the music of beautiful waters, the quiet of woodland roads, the kindly eyes of animals we had known, the memory of sun and moon and star long lost in the glare of electric lights, began to call. We sat down in our little narrow parlour, with its cast-iron firelogs and porcelain taper chandeliers, and cried over it all. 


\section{CHAPTER II}

\section{In Old Tidewater Virginia}

We moved to Tidewater Virginia, the home of Captain John Smith, the oldest settlement in America and yet the most primitive, the most beautiful and least known spot in our continent-a bit of wild nature slumbering beside the pathway of the rushing life of the Atlantic seaboard.

Here we realized the first dream of life, a stately Colonial home two hundred years old, called Elmington Manor, situated on the shores of the Chesapeake Bay. Its ivory pillars flash their welcome from both sides of the house through the shadows of huge trees that shade its wide lawn.

The farm has five hundred acres, three hundred and fifty under cultivation and one 


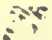

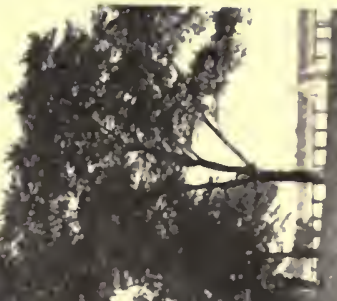

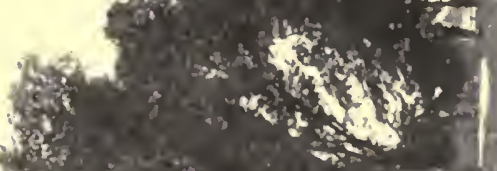
Hist

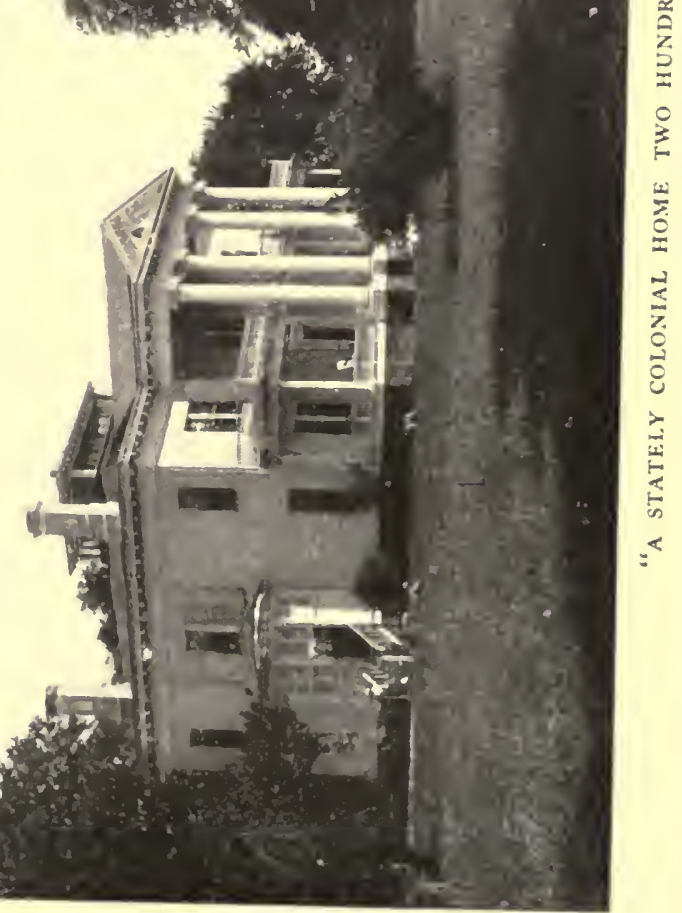





\section{In Old Tidewater Virginia}

hundred and fifty in woods. We keep eleven horses, six cows, a dozen sheep, four bird-dogs, chickens, ducks and turkeys. We have a two-acre garden with greenhouse for winter vegetables, an acre of strawberries, an acre of raspberries and dewberries and two acres in grapes; an old orchard and a young one with all the fruits of the temperate climate; and a mile water front with full riparian rights.

The Old Dominion steamer has an artistic little pier on the upper end of the lawn, which gives us daily mail and traffic with Old Point and Norfolk and the outside world. There are no railroads in the three counties of Gloucester, Matthews and Middlesex. We live in Gloucester, and around us on the beautiful landlocked arm of the Chesapeake called North River we see from our porch fourteen water-front homes. These three counties are intersected by a network of tide rivers and creeks, like the 
veins of a leaf, making it a veritable rural Venice.

Back two miles in the high hills rise cool streams of fresh water to turn our millwheels and pour their new life into the sea, giving us the finest oysters in the world. We have twenty-five acres of these oyster grounds in front of our home.

The fields are full of quail. They nest in the garden and orchard and sometimes mix with the chickens; while in unbroken reaches of three thousand acres of forests roam flocks of wild turkeys whose ancestors furnished food and sport for Powhatan, Pocahontas and Captain Smith.

The waters are full of fish, and our baby boy can catch enough for dinner within a hundred yards of the house any day from the first of May till the first of November. In the winter the wild ducks, geese and brant give the sport of kings.

We keep a pen full of diamond-back ter- 


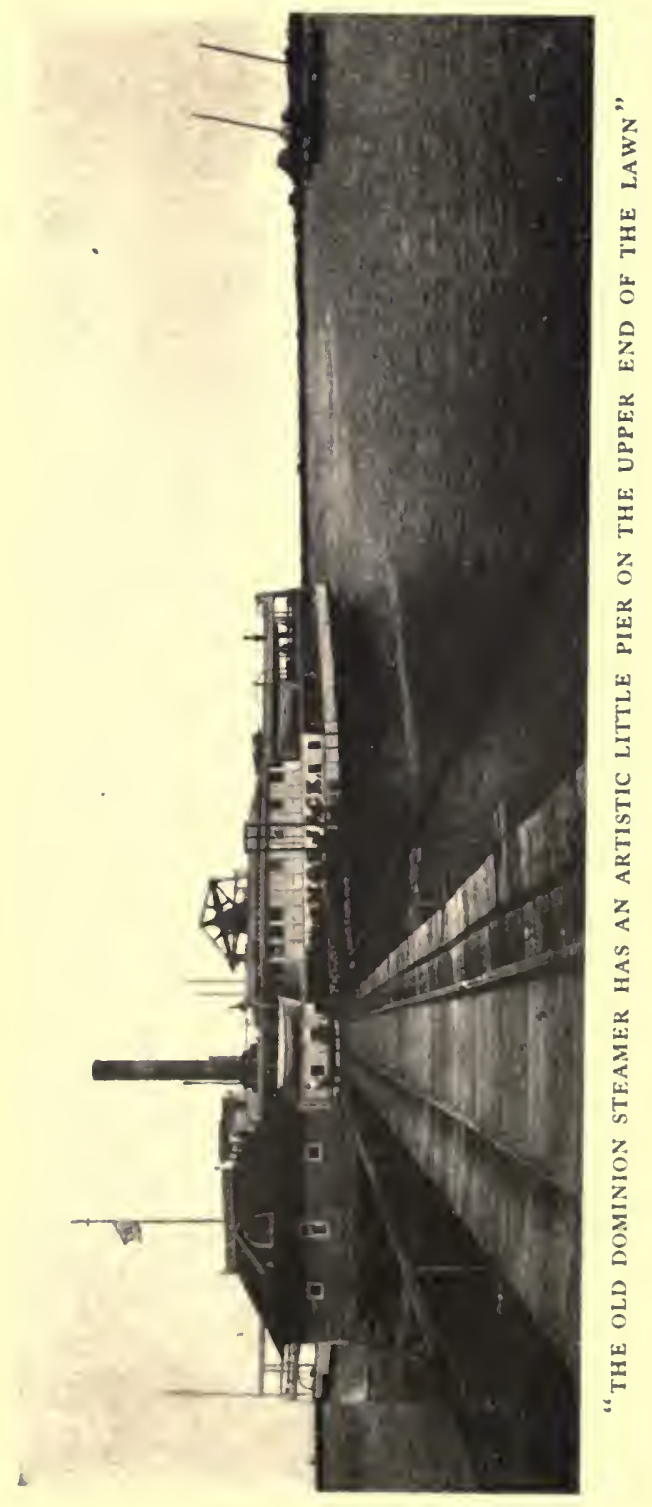



rapin as we keep a pen of pigs, and fatten them on crabs. Crabs and clams are so plentiful that they are considered a very plebeian diet. We keep a naphtha launch, two small sailboats, three rowboats and a schooner yacht.

I had always desired a home that had some association with history and yet one on which I might stamp the imprint of my own mind. Elmington Manor fulfilled both these desires. The house, when we bought the estate, was simply a square brick structure finished with Portland cement and painted brown. It is beautifully situated on a peninsula lawn of fifteen acres. From the land side the avenue drive stretches away from the gate through giant trees two miles to the hills and the country road. On the water side it looks majestically out to sea over a sunny stretch of greensward dotted with holly and flowering shrubs.

Its roots are deep set in Colonial history. Its broad acres were a Crown grant two hun- 
dred years ago. A short drive to the south is the village of Yorktown, the scene of the siege and surrender of Lord Cornwallis to Washington and our French allies. On this side the York River stands towering old Rosewell, the most palatial country establishment in America when built by the Pages. Near Rosewell is the ancient chimney of the Indian emperor, Powhatan. This chimney was built for Powhatan under the direction of Captain John Smith's colonists. Across the York but a few miles from us are old Williamsburg and Jamestown.

The house was built by Dr. John Prosser Tabb, fifty-seven years ago, at that time the richest and most influential man in the county. Its walls contain the brick from the old house built in the earliest Colonial days.

These walls are three feet thick. The house is three and a half stories high and contains thirty-two rooms. The hall is 


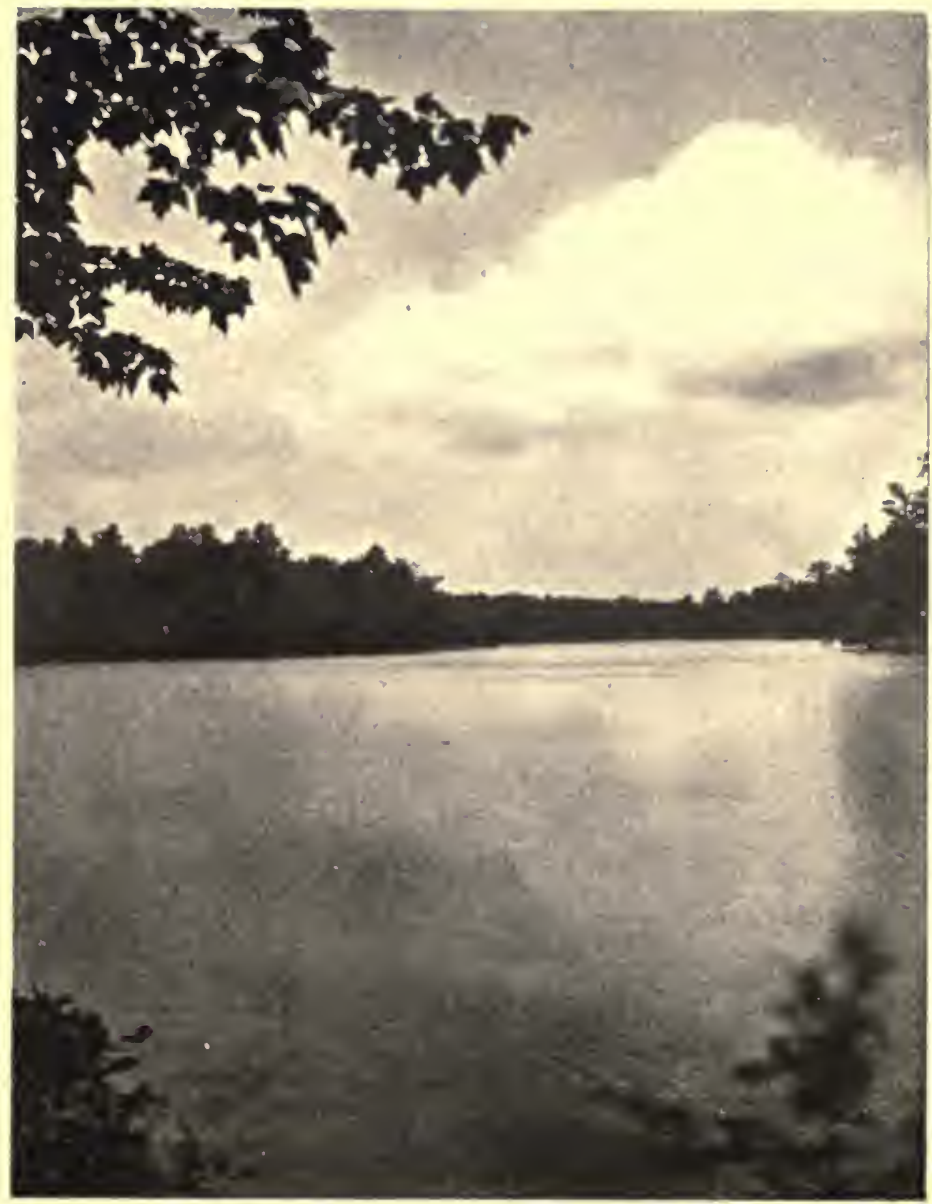

"IN THE HIGH HILLS RISE COOL STREAMS OF FRESH WATER TO TURN OUR MILL-WHEELS" 

twenty feet wide, and thirty-five feet deep; and from its rear circular wall the winding mahogany stair sweeps gracefully up three stories into the gallery of the observatory.

There is not a shoddy piece of work in it from cellar to attic. The mahogany rails and spindles are the finest finished handwork, the window and door sills are of massive Italian marble, and the hard pine floors so evenly and smoothly laid they will hold water. The floors are laid on oak sleepers set ten inches apart, and are back-plastered and sand-ballasted.

Hundreds of slaves aided the skilled workmen in its erection. Its straight, massive, square lines gave me the opportunity to carry out my dream of a Colonial home. It only required the addition on both sides of the Greek façades with the pillars, and it was done.

We had men at work on the construction of these columns who never saw a locomo- 
tive,-men of family who own their homes.

I put in a system of waterworks, with windmill for power, four bathrooms, and a complete system of sewerage into tidewater. An acetylene gas plant gives us finer lights than electricity and for less cost than city gas. We rummaged through the junk shops of New York and dragged out a complete set of massive brass chandeliers, all over fifty years old in pattern, had them cleaned at the factory, and they look as if they had been built into the house originally.

Twelve rooms have open grate fires, and sufficient heat for all the spaces was secured by placing two tubular hot-air furnaces in the basement. Our winters are usually so mild that roses blossom in the flower-garden in December.

I had dreamed this complete from the moment I saw the house. The actual doing of the thing was a revelation and a liberal education. I figured on $\$ 3,000$ for the job of 


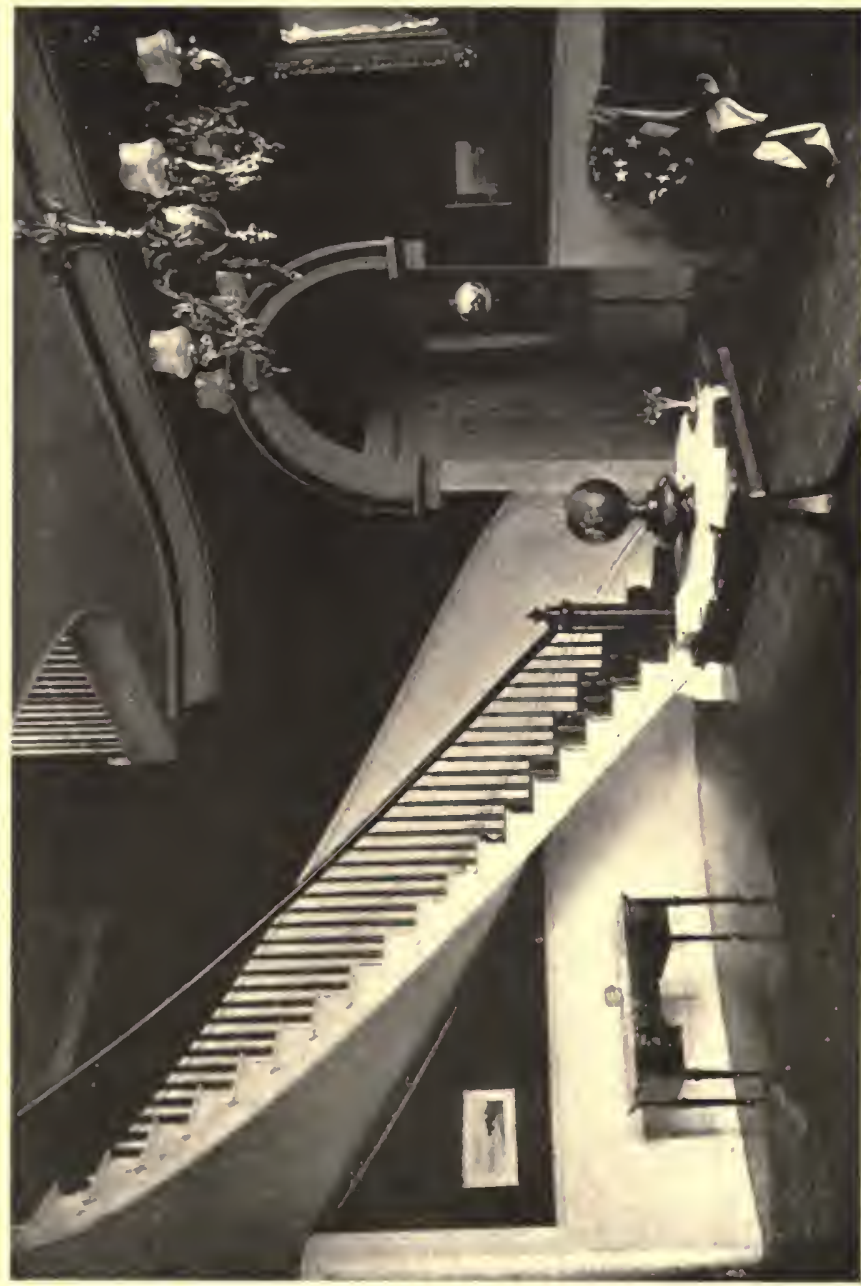

: 

painting, decorating, water, heat, and modern conveniences.

The plumbing alone cost $\$ 2,350$ ! And I got good value for the money. The bills aggregated $\$ 7,500$.

But when it was done, it was a joy to look at it. The effect was massive and dignified, and yet homelike and inviting. We had something to show for our money, and, what was a great deal better, we had something that would stand the test of time. Its great hall and grand old rooms with their lofty ceilings give meaning and dignity to daily life, and their memories link us in fellowship and sympathy to a mighty past.

And we got it all for nineteen feet of scorched mud in New York. 


\section{CHAPTER III}

\section{Beside Beautiful Waters}

It is the situation of a home that makes or mars it. Spend a million dollars on a palace, locate it poorly, and it is lost. You may build with all the art that genius and wealth can command, and if you build in an unhealthful climate or near a fish factory, art and wealth and genius have failed.

The one thing that makes New York impossible for a real home is the certainty that sooner or later a hotel, a flat, a store, a church, a factory, a stable or a saloon will be located near you. It is only a question of time when the palaces of millionaires are moved by these forces.

The thing which charmed me first with the spot in Tidewater Virginia which I selected, 


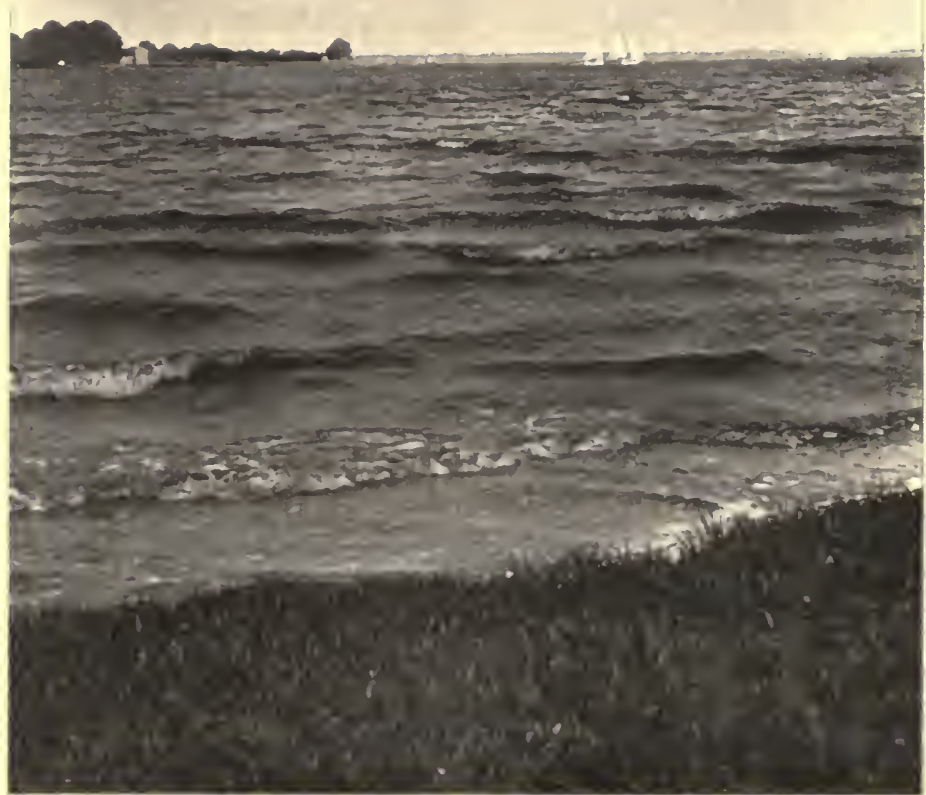

"THE GRASS OF THE LAWN ROLLS SHEER INTO THE DEAD LINE OF THE SALT TIDE" 

is the fact of its perfect healthfulness and security from nuisance.

The lawn is high ground rising abruptly from eight to ten feet from the water line, a stiff clay soil mixed with sand, with no marsh grass or mosquito pools. The grass of the lawn rolls sheer into the dead line of the salt tide. There are mosquitoes and malaria in Tidewater Virginia if you choose their location. The lawn of Elmington Manor is a beautiful little peninsula behind which stretches the estate of five hundred acres into the hills.

This little peninsula juts out into the waters of the river at the head of its navigable channel, just where the current makes a sharp bend to the right and two large creeks sweep inland to the left, giving views of the water from every window in the house and from every point at which a rustic seat may be placed on the lawn. The creek flows gracefully through the lawn 
and forms a landlocked harbor for our boats.

The water front commands an entrancing view. Straight before, two miles wide, stretches the North River southward until lost in the open sea of the Chesapeake Bay and Atlantic Ocean. The shores are marked with towering trees clustering around their old homesteads.

The things which fascinate me above all others are our trees.

The place was named "Elmington" from its giant elms. On the lawn now are three hundred and ninety trees, comprising thirtyseven varieties. About half of them are the evergreens, holly, pine, cedar and magnolia. Among them are water oaks four feet in diameter, lifting their immense limbs clothed in shimmering green far above the roof of the house.

There is no sameness anywhere. The lawn is level only on two sides. On the 


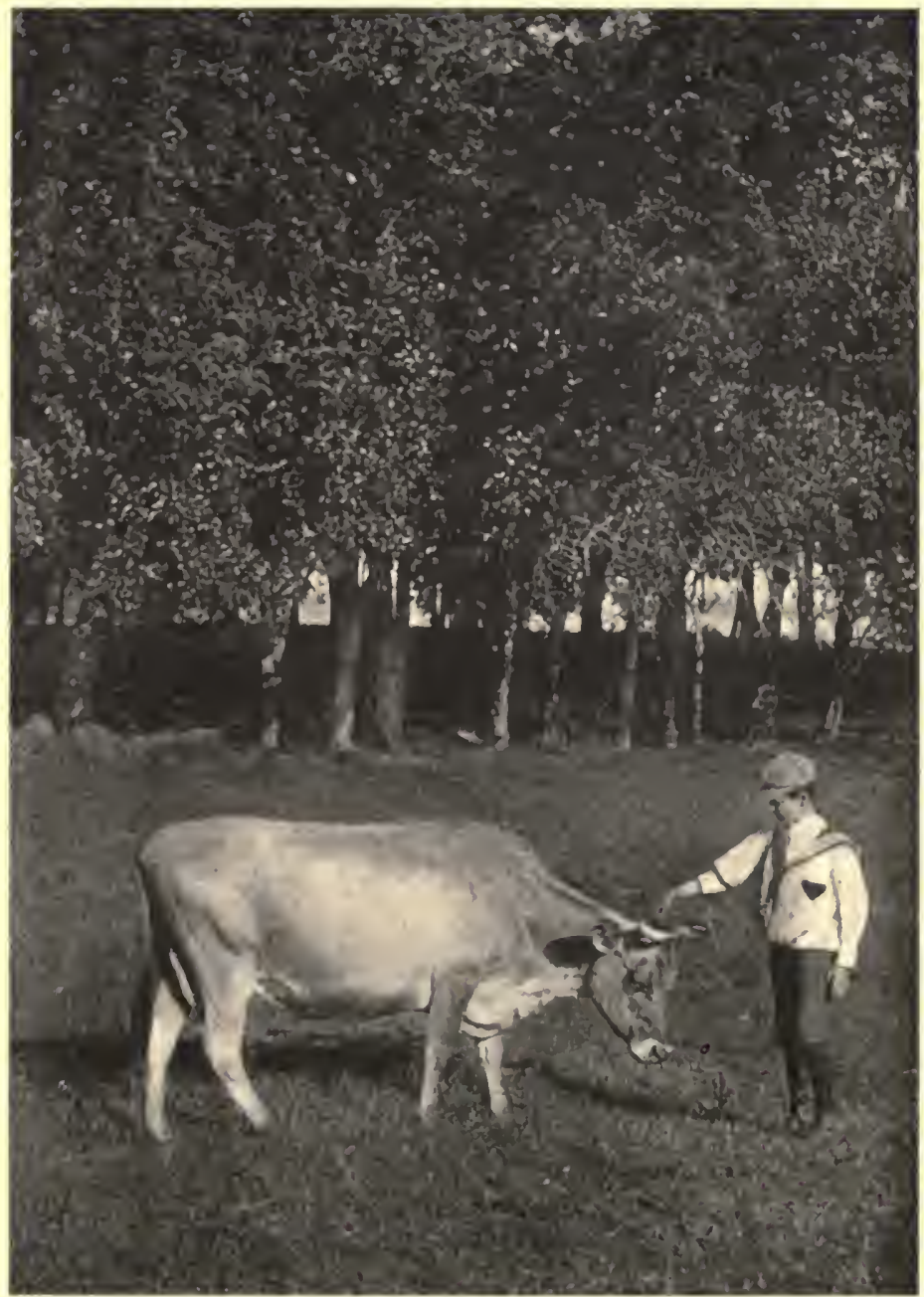



other sides are little hills and valleys and long open reaches of sunlit turf. A hundred cedars tower in line along the northern and western sides as guarding sentinels against the winds of winter. Two big magnolias, robed in everlasting green, stand beside the white pillars on the front porch and blossom all summer.

On the water side the hollies cast their dense shade in summer and lift triumphantly their bouquets of scarlet berry and green leaves through the fiercest storms of winter.

A mockingbird builds every summer in the flowering holly which we see on the water's edge from the dining-room window, while another nests in the rosebush nearby, and from every shrub and tree the chatter and song of an army of feathered musicians fill the air with melody.

We have nothing artificial, forced or cultivated-only the trees, hardy shrubs, grass and wild flowers. 
Our friends from the barn with their babies often roam over the lawn, and their fellowship more than pays for any annoyances their presence may cause. They drink gracefully at our mermaid fountain and seem to think her bronze figure was cast and set there to give them water. And so it was.

In early spring the buttercups carpet every inch of earth in gorgeous yellow, while the jonquils lift their flame about the fountain's rim.

The buttercups stay a month, and then forget-me-nots, clover and daisies add their white and blue. We have a garden for the cultivated flowers. But I confess I've given my heart to the wild flowers of the lawn. They ask nothing and give everything.

The oaks and elms I love best of all the trees, especially the water oaks. When tired of study, I stroll beneath their dark shadows, while their satin leaves flash above in the sun like so many swinging diamonds, lie down 


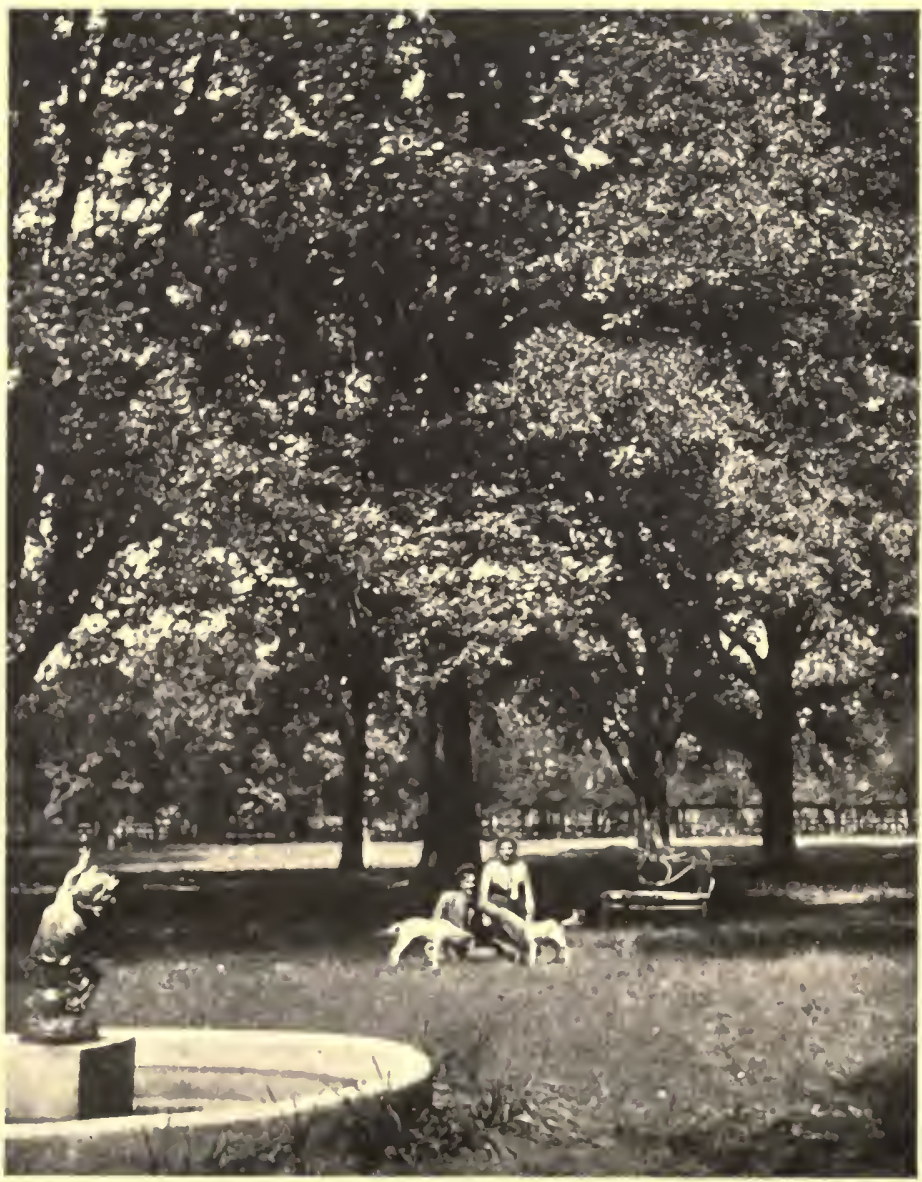

"IHE OAKS AND ELMS I LOVE BEST" 

on the grass, and rest. Ah, such rest, with my beloved near!

The rush and roar and stupid din of the city I remember only as a fevered dream. I am akin to all life. The earth beneath is soft and tender as the touch of a mother, and these oaks that tower above me are my brothers. They have been tried as I have been tried. Their limbs have wrestled with the furies that rode on the wings of storms and have conquered. Their fibre is strong because they have suffered. The last storm twisted off the top of a mulberry and hurled it to the ground. But the oaks laughed for sheer joy in their strength when the wind was fiercest. I love them because they are strong. I hear them at night softly sighing when the wind is gentle. They are telling the others about them to be not afraid, for they have looked far out to sea and no storm is near.

Through the shadows of the trees the waters gleam. 
How any man can build his home away from water so long as there is a water front left is something I cannot understand. The house is located just two hundred feet from the river's edge from one corner of the porch, and from the other corner the lawn stretches away into a reach of three hundred yards of open greensward before it merges into the tide.

This flashing glory of opal, emerald, and turquoise water, changing its tint with every passing cloud and breath of wind, reflecting every mood of sky and shore, with each whitewinged sail that skims its surface-all now are of the rhythm of our very life. The storm, with its ten thousand whitecaps dancing and foaming and thundering on the shore, the mirrored pictures of the calm, the endless panorama of sun and moon and star are ours for the lifting of the eye.

And we got it all in exchange for a few feet of scorched mud, and a cement cat-yard $19 \times 20$. 

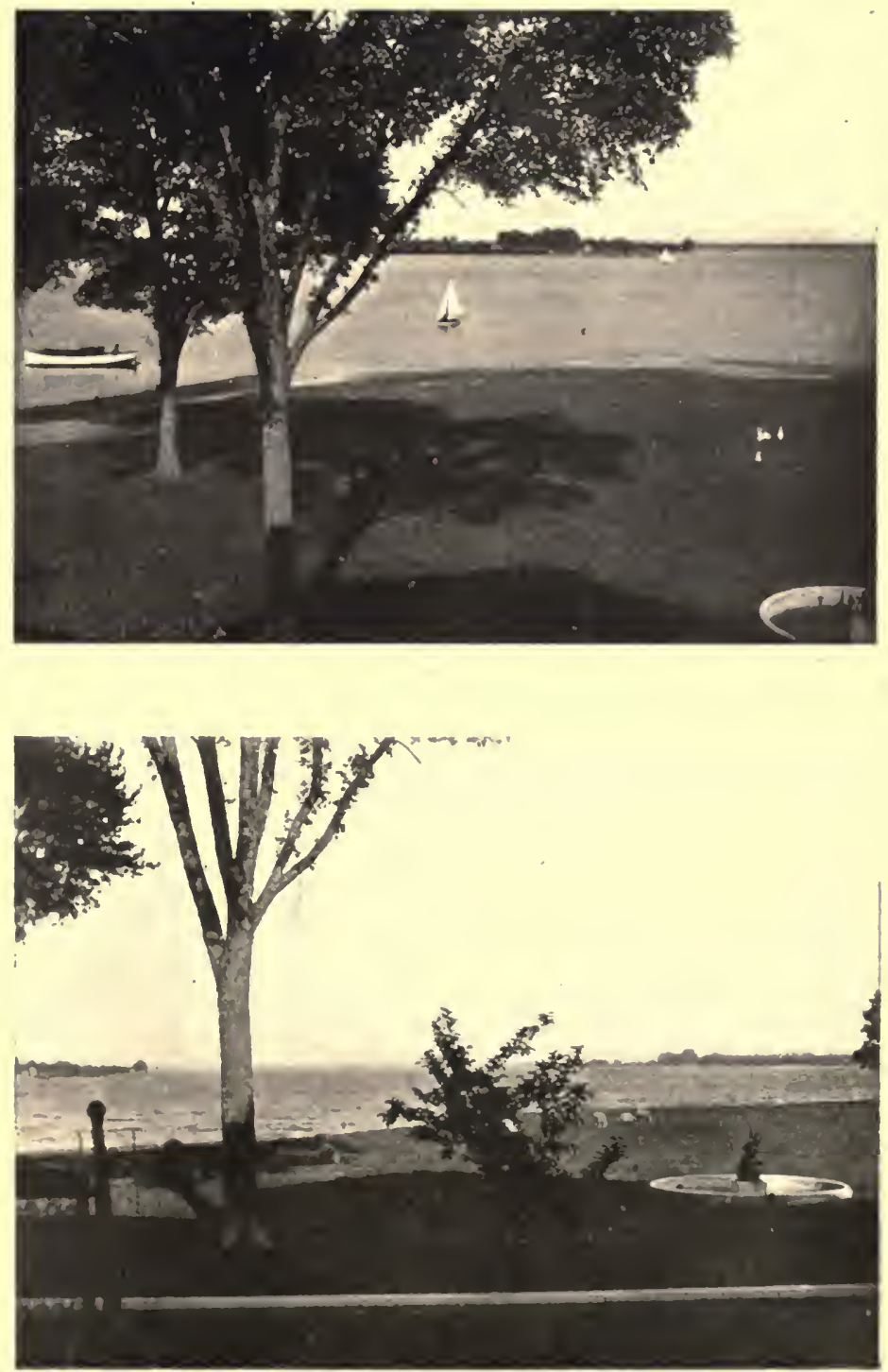

"THROUGH THE SHADOWS OF THE TREES THE WATERS GLEAM" 



\section{CHAPTER IV}

\section{The Music of the Seasons}

Old Tidewater Virginia is the ideal spot in America for a home all the year round. Northern people have a very erroneous idea of the heat of its summers. I have spent summers at Gloucester, Massachusetts, on Long Island, and the Jersey coast; but there is no place on the Atlantic that compares in comfort to the shores of Old Virginia. The Gulf Stream, which almost touches the beaches here, maintains its temperature of 70 the year round. In winter it tempers the cold, and in summer it lowers the heat. We have the most even temperature to be found in the East.

We have long, beautiful springs. Winter never lingers in the lap of spring 'until it 
creates talk.' The earth seems alive with every species of early wild flowers.

The vegetable garden is a source of endless pleasure. We plant peas in January, and cabbage and lettuce grow all winter.

There is something about planting seeds, watching them sprout and grow, that links one with the creative process.

Production is communion with God, however stoutly the dogmatist may deny it.

I plant the seed in the soft warm earth and feel the glow of creative joy. I have joined with God in giving life, and when I reap my harvest, I join with him in taking it again.

There is not a month in the year that our garden will not grow the hardy vegetables, and from March to November it grows everything that flourishes this side the tropics. Celery will keep all winter bedded in the ground where it grows.

The spring calls the sportsman as loudly as the fall. 


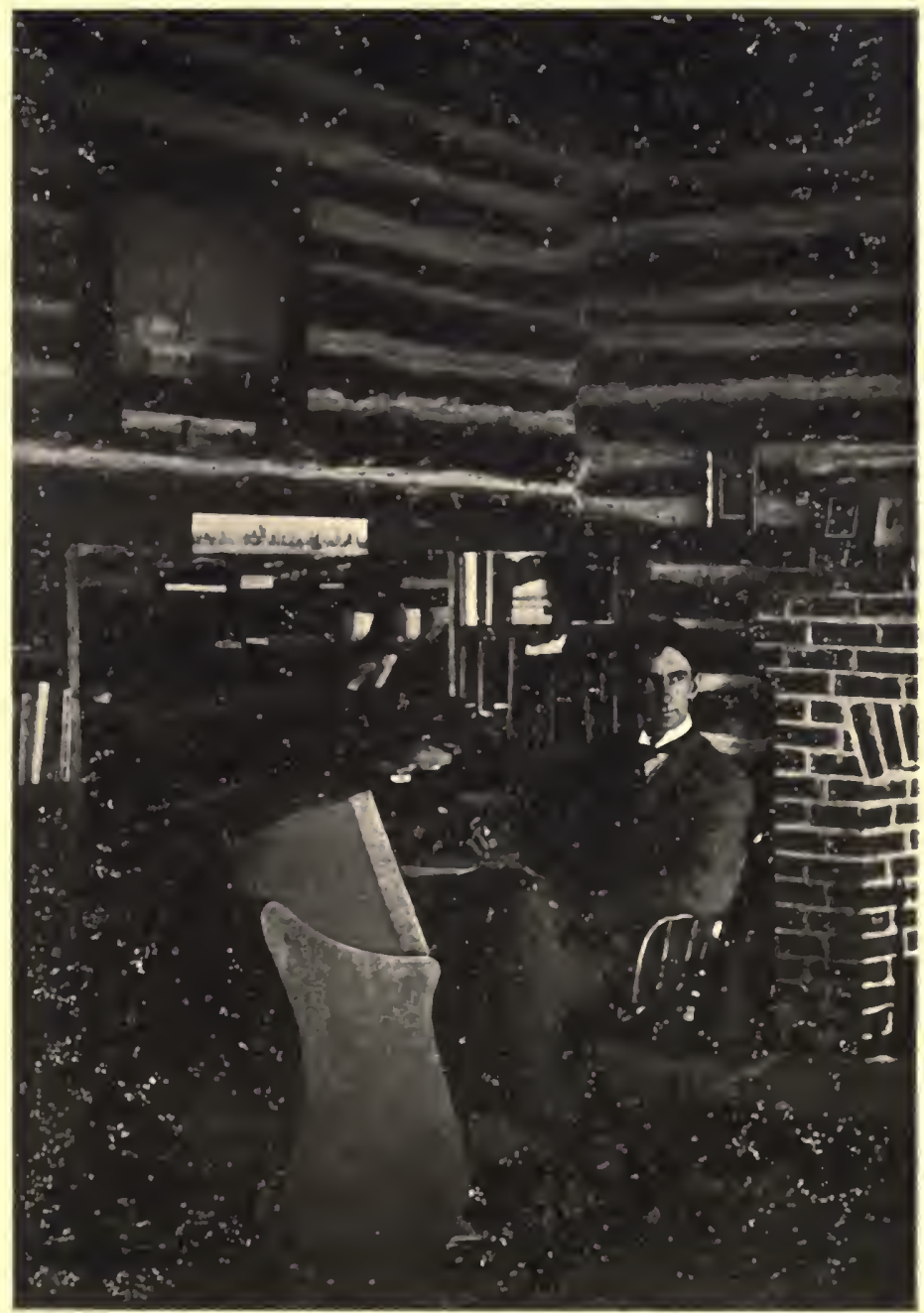



The fishing is fine, and the shore birds, curlew, snipe and plover, come in myriads in April and May and spend six weeks getting fat as they migrate northward. They have raised their young in the winter, far south, and spring is the proper season to kill them for food. They leave in the latter part of May and stop again as they return southward in July and August. They do not nest or stay permanently in our territory. Tidewater Virginia is simply their rich feeding ground.

In summer we have delightful breezes from every point of the compass. The long sweep inland of the Chesapeake Bay for 200 miles makes a hot land breeze impossible. The land breezes on the coast of New Jersey are insufferable to me. Here is water, water everywhere, and the land seems always the least significant feature of the picture Nature presents.

The fruits of the semi-tropical zone all grow 
luxuriantly. Gloucester county is famous for its fine watermelons and cantaloupes.

The drives in summer along the country roads are of surprising beauty. The wild grapevines festoon its dense woods and hang far out over the roadway. Even at noon the wide double-track highway is sheltered by these cooling shadows.

The summers offer the sportsman the same flight of migratory shore birds as spring, and adds to them some special varieties.

Autumn clothes field and forest with a new and peculiar glory. Here we have the long Indian Summer in September and October. Italy never saw such skies, and the glorious sunlight and peace that flood the earth in these days cannot be revealed by words. October is the only month when the windmill ever fails for two days to turn. Nature seems to hold her breath for sheer joy. Each day is a miracle of beauty-clear skies, warm genial sun, crisp pure air, with every 


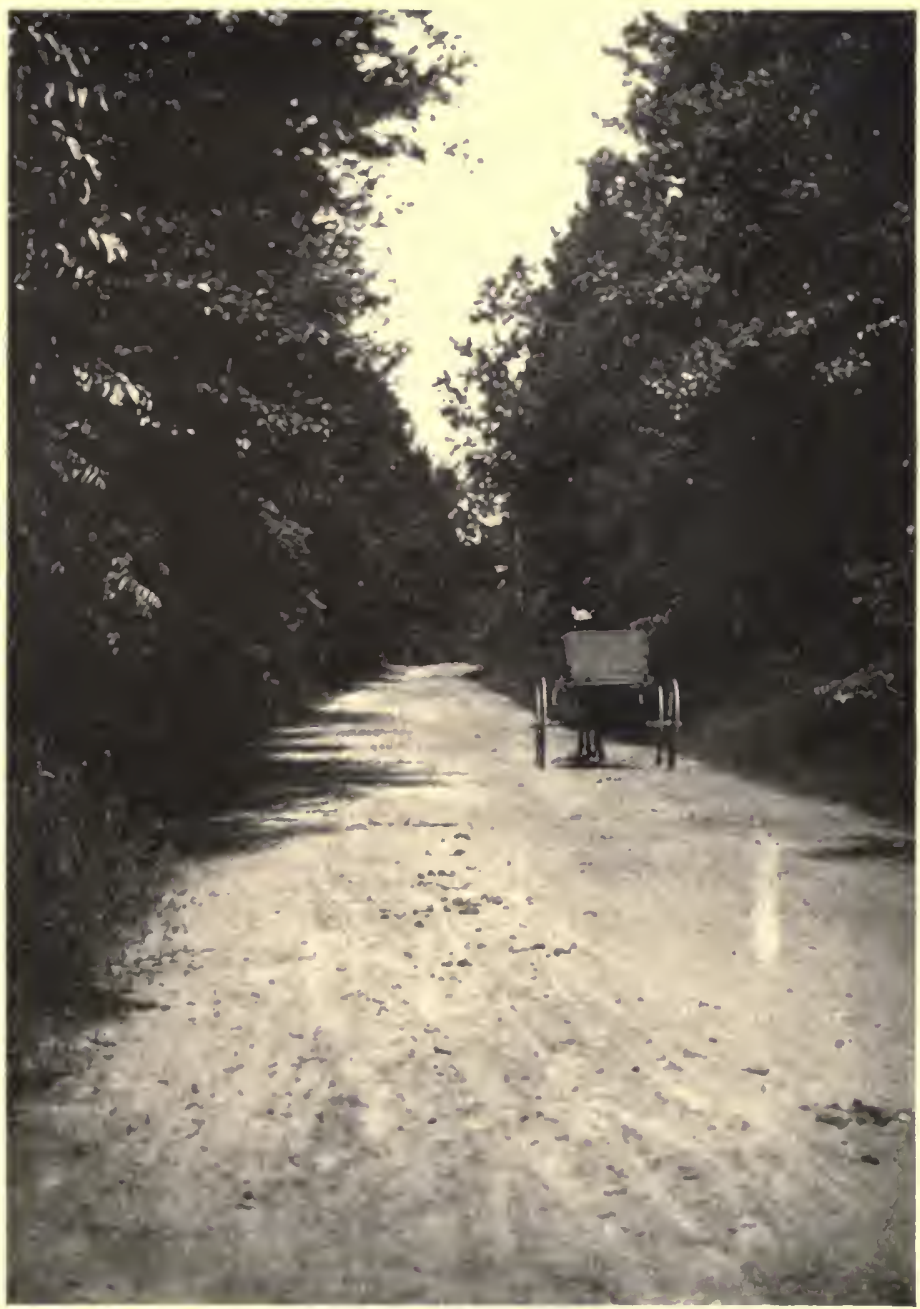

"THE DRIVES IN SUMMER ALONG THE COUNTRY ROADS ARE OF SURPRISING BEAUTY" 

tree that sheds its leaf robed in scarlet and purple flame.

It is hard to tell when our woods are most beautiful: in spring, with the dogwood blossoms so thick they look as if a snowstorm had covered their tender green, or in October, when the holly, as thick as the dogwood, lifts its great bouquets of glistening evergreen with scarlet berries amid the red and purple splendour of the oak and hickory, beech and maple, poplar and chestnut.

I confess a special love for our winters. Here the fire of the sun never dies. It warms and thrills even in February. The lawn is never quite bare. When the winds of November have swept clean the great limbs of oak and elm, the magnolia, cedar and holly smile still into the face of the sun. I love these big naked trees, too. To me their tall nymph-like limbs seem fashioned by some master artist of the nude against the azure background of the sky. 
The roads in winter, that stretch through solemn aisles of towering pines, are as beautiful to me as the embowered drives of summer.

I love the ragged winter lines of the creek where the quail shelter in the tall grass at the water's edge ready to cross to the woods if hard pressed.

The cry of the wild duck and brant and the honk of the goose thrill the heart of the huntsman and call to the sport of kings.

There is not a day in the calendar from the first of January to the thirty-first of December that there is not good fishing or hunting, or both, in Tidewater Virginia.

On long winter nights we sit beside a roaring log fire, read and dream, listen to music, or chat with our kindly neighbours. Our neighbours are never in a hurry. They have more time than money, and spend it more freely. They really live, and we have fallen into their friendly ways. 


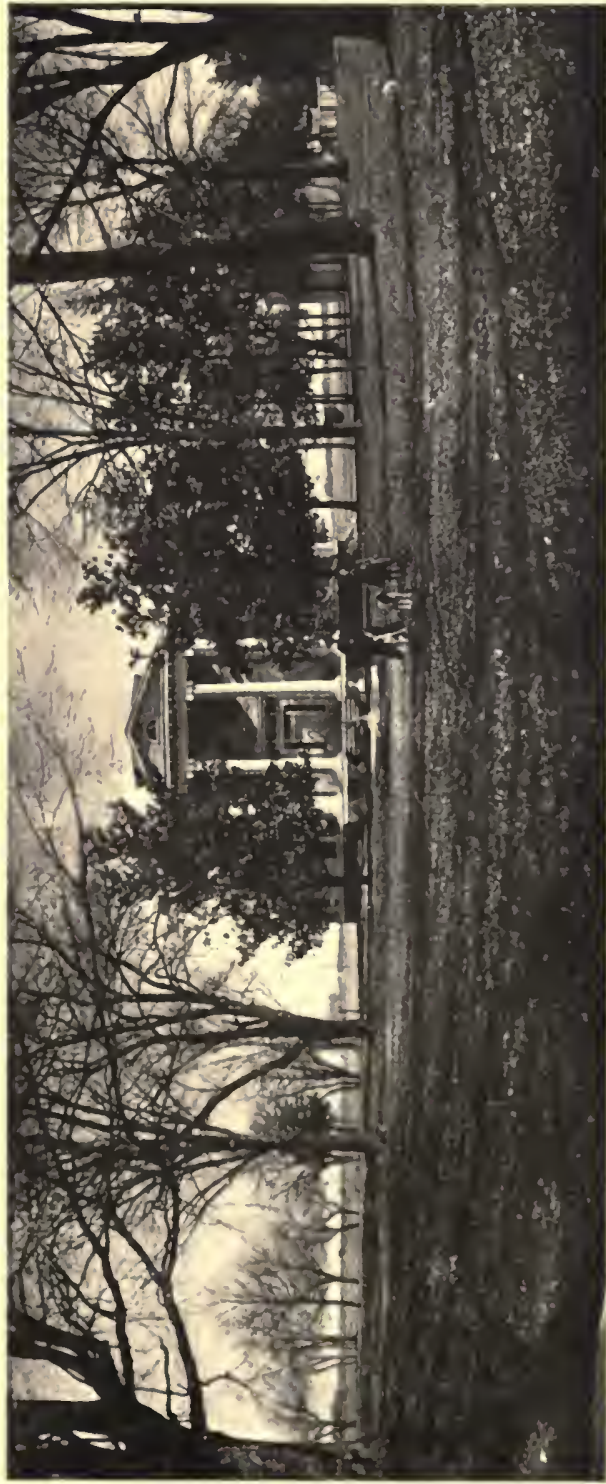

: 



\section{CHAPTER V}

\section{The Fellowship of Dogs}

Perhaps the most pitiful thing about the stunted life of a man or a boy in the city, is the lack of healthy dog comradeship.

The cynic who said, "The more I see of men the better I like dogs," was speaking of men who had degenerated for the lack of the friendship and personal sympathy of dogs.

The dog is the most faithful, the most lovable, the most companionable of all the animals that associate with man, and man is always made nobler by his friendship.

Let no fool philosopher tell me a dog can't think, reason, love, hate, fear, laugh and cry as I do. I know better.

When I reached home the other day from a long lecture tour, my oldest setter hadn't 
been out of the lawn for two weeks. She scorned to follow the carriage and point birds for women and children, who were incapable of appreciating her genius. But when I came-such capers, such exclamations of love and joy! She cried-literally cried big tears of joy-laid her head against mine, and between her sobs told me I had missed the greatest quail season ever known in Virginia. She said the quail were so thick they were coming into the yard, and that nobody had sense enough to go after them. She begged me to go outside the gate with her, in season or out, she didn't care, and she would show me.

When I drove out with my wife, Becky was simply beside herself with joy. She danced and capered around the carriage and said with a smile:

"Now just watch me. I'll show you a dozen between here and the county road!"

We had barely passed through the gate, 

when she circled gracefully through the strawberry patch, made a beautiful point, turned her head toward the carriage, grinned, switched her tail and said: "I told you so! Look at this!"

When I flushed the birds she sailed swiftly away to the next field a hundred yards farther, and before we reached the point in the road she had rounded up more birds.

When I flushed them, she looked up at me, smiled and said with a sigh:

"You see they are all in pairs now-it's too late. I nearly died of a broken heart because you didn't come in time. I lost my appetite and all interest in life and wouldn't go out of the yard. You will not stay away so long again, will you?"

I assured her that I had already arranged my lecture-trips season so that I could be with her the month of November and December, and she wagged her tail and smiled.

One of the smartest things I ever knew 
Becky to do was to take hold of my pantaloons, lead me around behind the house, and introduce me to her puppies born in my absence.

I saw there was something on her mind. She seemed ashamed and troubled lest somebody would tell me before she had a chance to explain. So she led me in haste to her modest cottage behind the servants quarters before she would allow me to enter the house.

"You see it was like this, sir," she said with confusion; "I know you don't like droppers, and it's not considered good form in aristocratic society for a setter to mate with a pointer, but really I couldn't resist Bob. He was so handsome and stylish and we were thrown together so much, it all came about quite naturally. We hunted together and Bob stood so beautifully and found so many birds and was so kind to me-I confess-I lost my heart. And when he asked me to 


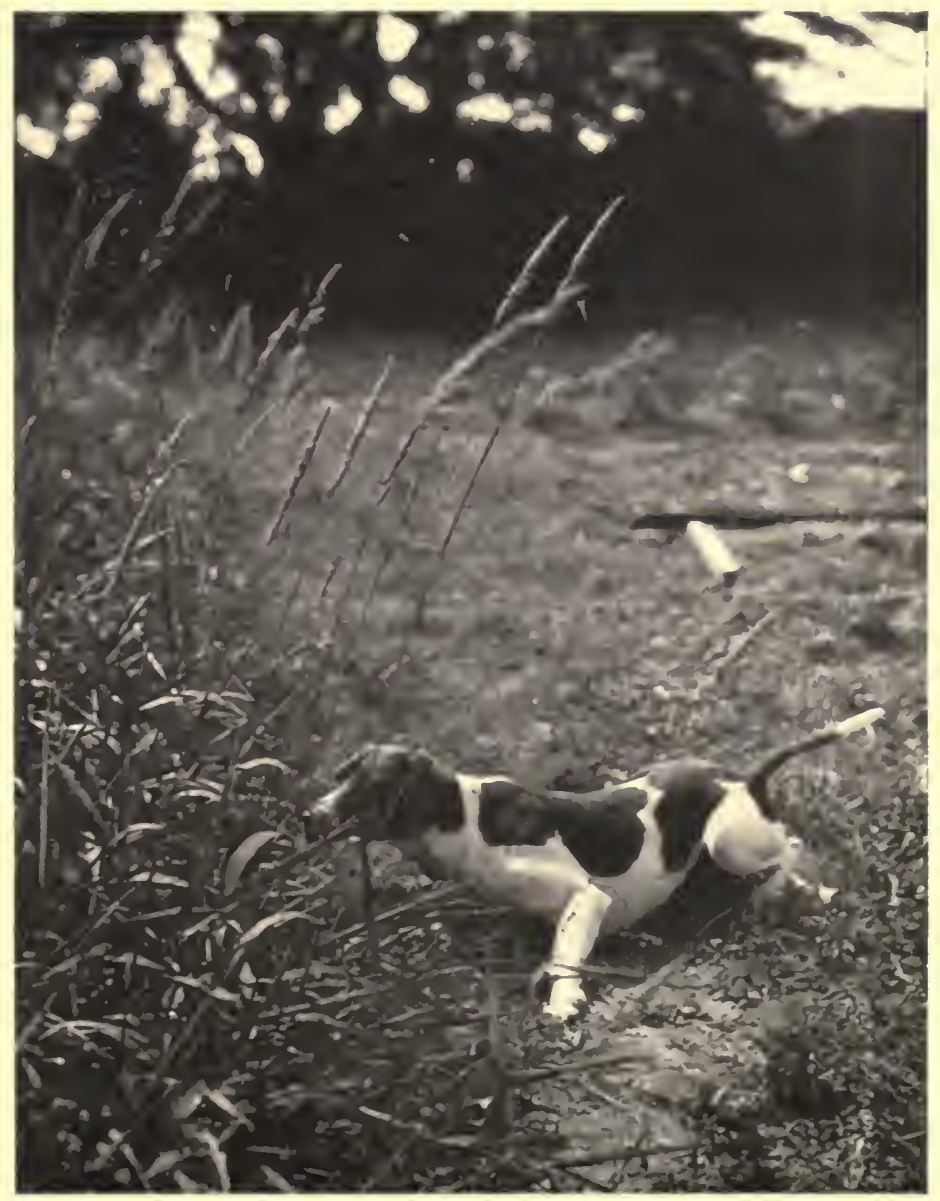



marry him, I knew I was doing a wicked thing to disobey you, but-we eloped."

"Why, Becky, I'm astonished at you!"

She hung her head and stammered incoherently, but looking up with a smile said:

"Yes, sir, but you haven't seen 'emcome, look at 'em. They're every one of them raving beauties. You see, I was so in love with Bob, they all took after him. Not one of them seems to have a drop of setter blood in him. They all have the short silky hair of their father and the most beautiful spots!"

It was true. Every one of them was a pointer and the cutest little fellows I ever saw.

When Becky saw I was pleased she began to sob.

"There, there, Becky, it's all right now; we will make fine hunters out of them, and nobody will ever suspect they are droppers." "You see, sir, I've been so lonely since 
Sailor's death I had to marry again, and I must say Bob is the handsomest dog I ever knew, and he can't help that he's a pointer." "Very well, I'll provide for your children, and see that they are properly educated. If any one tries to insult you in your set, let me know and I'11 protect you."

"It was not that I had forgotten Sailor, sir, but he was dead and I was lonely."

"Yes, I know; it's an old, old story. You have good precedents."

Becky. knew that I had loved her former mate, Sailor, above all the dogs I had ever known. They were both born in North Carolina, the home of fine field dogs.

Sailor was a beautiful white and black Llewellyn setter, whose white tail flying above the grass looked like a sail skimming the sea, and from this he got his name. $\mathrm{He}$ could find more birds than any four dogs that ever went into the field with him, and do it quicker. He was a fine watchdog. When 


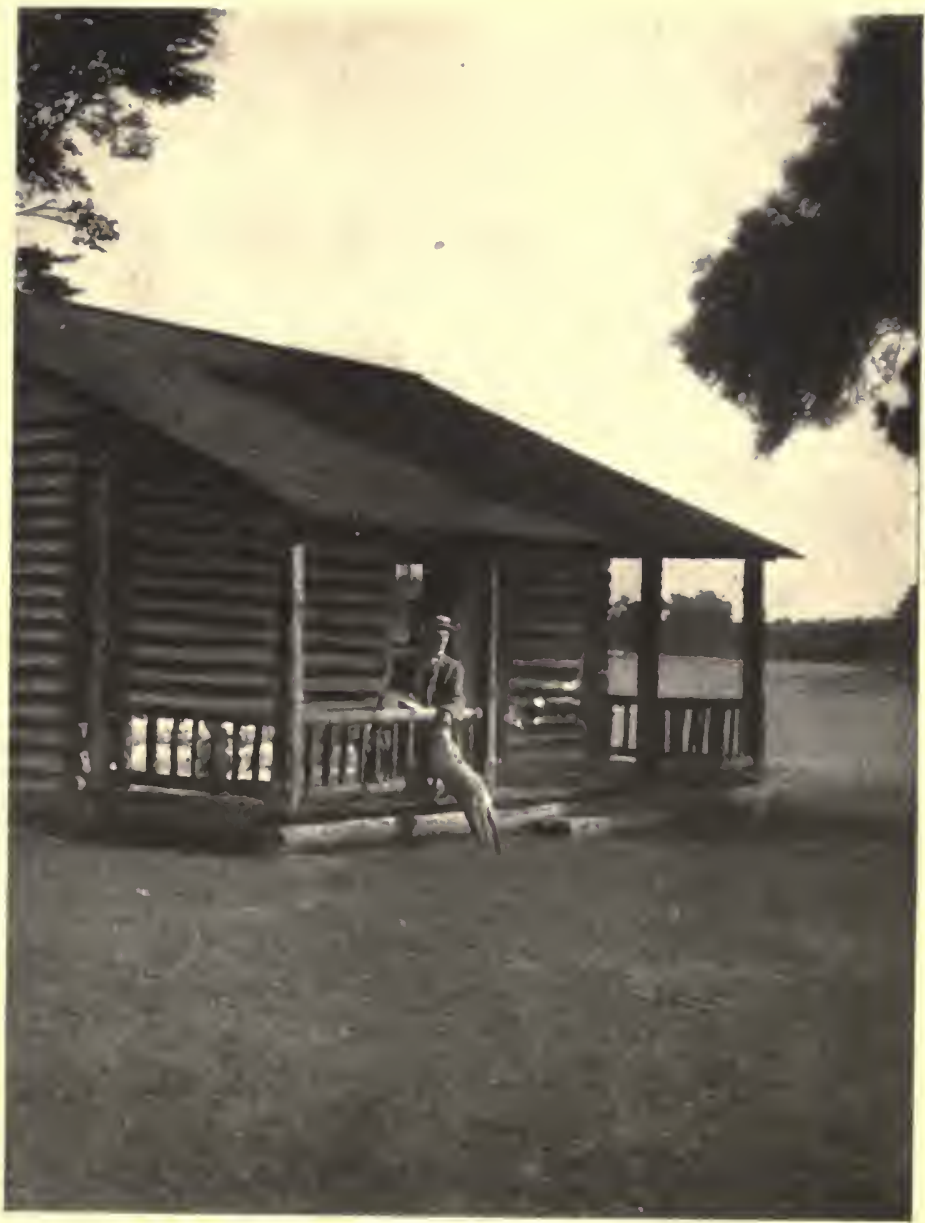

THE LOG-CABIN STUDY ON THE EDGE OF THE I.AWN 

I was away from home he slept in his mistress' room and I believe he would have torn an intruder to pieces at a single word from her.

Sailor had strange powers of observation for a dog, and many special likes and dislikes. He could spot a crank or a fool among a gang of workmen and would watch his opportunity to snap him. We had at one time thirtyfive workingmen here every day. Some of them stayed months. Among them was a poor white man who was a quack doctor, a quack preacher, and a quack workman. Sailor spotted him by some subtle power of reasoning the first day he landed and tried to bite him. That man stayed around our place tinkering at various jobs for two months, and the dog managed to tear his pantaloons three times and got one good crack at his leg, and he was never known to disturb any other workman.

When he first arrived from North Caro- 
lina, he was two years old and not very good looking. I got him in the spring and had to keep him all summer before I could try him. I didn't like his movements and in general thought him a failure. $\mathrm{He}$ was passionately fond of a horse-a rather unusual trait for $\dot{a}$ bird-dog. So I sent him to the stable and never allowed him to see the inside of the house.

When the first of November came, I took him out in the field for a trial with little faith in his ability.

The way he swept that field fairly took my breath!

The other dogs simply were not in his class. He was the whole show. He would circle a hedgerow like a white streak of light, suddenly dart out into the open, his beautiful head flung high in the air, and have the birds before the other dogs had started.

I hugged him. When we returned home that night he knew the change in his status 
in that household. He walked proudly into the library and lay down on the rug at my feet without waiting for an invitation. He knew the place belonged to him.

Sailor and Becky had only been married six months, and their first brood of puppies were three months old when he developed an ugly growth on one of his legs. I took him to a hospital in New York near Herald Square and a distinguished English dog surgeon performed an operation and removed the growth. He did well with the wound and in ten days was ready to go home.

How he wept for joy when I came to take him, told me of his suffering under the knife, and how he longed for the sight of my face and the sound of my voice! I explained to him that I didn't come because I couldn't bear to see him suffer.

"And, Master," he sobbed, "the awful loneliness these ten days I was getting well, and you only stayed a minute or two! I had 
to endure the vile talk of these ignorant and degenerate city dogs. All they know is the latest brand of vile dog biscuits that I wouldn't give a cur to eat, or about some collar they wore or a new coat for a party, or the last fight they had in Central Park on Sunday. It made me sicker than ever. Not one of them ever saw a rabbit or a quail or a woodcock. I asked one of them-a real setter too-if the dogs up here were good on a back stand or did they crowd much. The fool didn't know what I was talking about and yelled back at me: "Listen at the hayseed! He don't know a street car from a milk wagon! Wow, Wow!" And the whole mob of the ill-mannered brutes yelled at me, until I crawled back in a corner, lay down and cried for shame that I was a dog. I'm glad we're going home. I'm sick for the open fields and the cool water of the springs and the branches, and I've dreamed day and night of the bircis." 


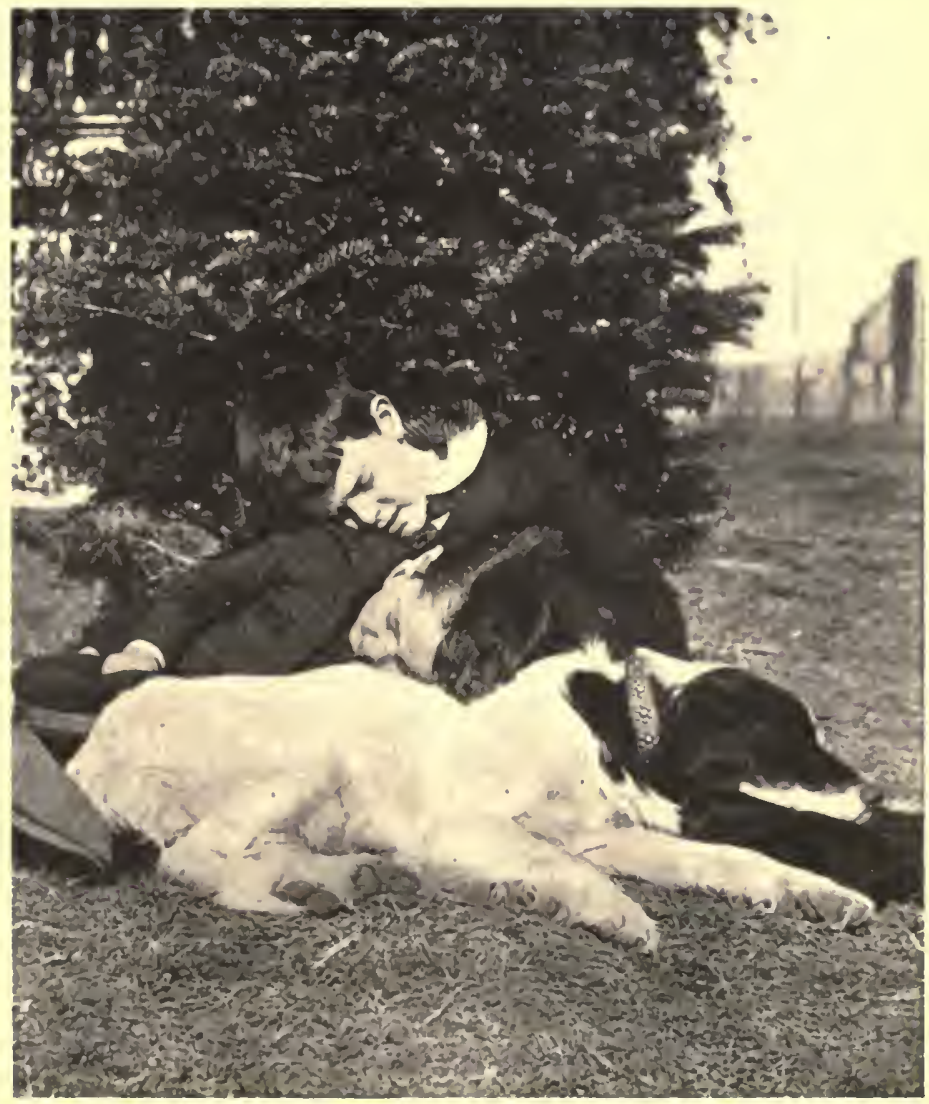

SAILOR AND THE BOYS IN PRIVATE THEATRICALS"THE MYSTEKY OF SLEEP" 

When the cabman was assisting Sailor down stairs and into the cab, the doctor gravely whispered:

"I'm sorry to tell you, sir, but your dog can't live long. He has a tumor developing in the groin which will kill him within a year or two. He can hunt all right up to the day it strikes a vital organ and then he will go."

He seemed so happy, with his head out the cab window sniffing contemptuously at the poor little chained and collared dogs he saw on the streets! Now and then he would lick my hand with a grateful dog kiss for what I had done for him and for the joy of home that was in his soul. How could I tell him the fatal secret that Death had already laid his hand on his silken hair and claimed him as his own?

A little while longer we would smell the fields together and our hearts thrill with the joy of the chase, and he would go. I wondered where! And my heart was heavy. 
We had two more glorious seasons together, and as the end drew nearer he seemed brighter, swifter and more human in his intelligence.

The second summer after the doctor's verdict, he suddenly dropped, one day, under the shadow of a great elm on the lawn. Death had called him, and he crouched and shivered at my feet afraid of his new Master. I tenderly smoothed his beautiful hair. $\mathrm{He}$ looked up into my face at last, his great soft eyes full of a strange terror. Unable to bear it, I started to leave him. He staggered to his feet and tried to follow me, took three steps forward, stumbled and fell. 


\section{CHAPTER VI}

\section{Some Sins of Nature}

Where else on earth is the general cussedness of things so vividly displayed as on a farm? The farm is the great School of Life, and no man's early education is fairly begun until he has taken a course on it.

I tried to keep out of farming when I bought my country home. An early training behind the plough was my inheritance as a boy.

I knew it was not all poetry.

The estate was in the hands of executors for sale as a whole. In vain I pleaded for the lawn and garden and fifty acres to tinker with. The price fixed for the house and lawn and fifty acres was just as large as for the whole place of five hundred acres. I didn't 
understand the sarcasm of this till long after. The temptation could not be resisted. There was a lordly suggestion about "broad acres," and there was a challenge in the soil and sky that roused my fighting blood. I longed to conquer, subdue and make it fruitful.

Besides, I had a sneaking idea that I knew more about farming than any farmer of my acquaintance. All that was necessary was a large opportunity to demonstrate the breadth of my genius. I got it.

First, I determined to get rich on fancy truck farming.

The people of Gloucester, who had no railroads, were slow and ultra-conservative. I determined to hustle after the manner of the Yankee and the Westerner, and show them how to do things.

I put in fifty acres of Rockyford cantaloupes and ten acres in cabbage. I had no idea how many cabbage plants could be set in ten acres of ground before. 
I knew after I paid for the labour.

I had a gang of men at work a week on it, after patient and careful preparation of the soil with the most expensive commercial fertilizer. In the winter I studied the weather with nervous fear for those thousands of precious cabbage plants. They pulled through well, with the loss of about twenty per cent. In the early spring the worms and bugs and lice in succession attacked them and we lost twenty per cent. more. But by rapid working and high fertilizing we pushed them ahead of these pests. Then they began to go crazy and run up to seed and blossom instead of making cabbage heads. Five per cent. more were lost in these seed stalks.

At last the day came for marketing. It was a day of excitement. They were selling in the New York market for $\$ 2.25$ a crate, by the papers, and that meant a neat profit on the field. I began to pity my neighbours who were still struggling with common farming. 
My triumph was brief. I got 75 cents a crate for my first shipment. They cost a dollar at the most conservative estimate. The next shipment brought 25 cents a crate, and the next one was held for the freight charges and dumped by the transportation company. I sent the ploughs into the field and tenderly turned under for fertilizer my crop of cabbage over which I had toiled and yearned and dreamed. I quietly determined to let somebody else raise cabbage.

My cantaloupes grew beautifully. I'm especially fond of a fine cantaloupe and I determined, for the sheer love of the thing, to grow the finest melon New York ever tasted. I did it. The first shipment, however, gave me a chill. Instead of $\$_{3}$ a crate I had expected, I got an average of 85 cents a crate. They cost me $\$$ I.25. The next shipment brought 50 cents, and the next 25 cents.

I had nervous prostration and went to 
New York to study the distribution problem in connection with production.

I found my commission man was also a retail dealer, and that he sold my melons to himself and then sold them to his trade, and that this was the rule, not the exception. I found my melons in the refrigerator of a great hotel, and the steward informed me they were the finest ever seen on the New York market. He didn't know why I was inter. ested and I let him talk. He told me he paid the commission merchant to whom I had shipped them $\$ 3.50$ a crate. He was paying me 25 cents.

I had a pleasant interview with this commission-retailer who was kindly assisting me to bankruptcy. His explanation was so beautiful, so plausible, so incontrovertible I had to thank him and ask his pardon for disturbing him while he was figuring out his profits. He said the melons were so roughly handled by the steamship company (our Old 
Dominion Line is one of the most careful freighters in America) and arrived in such bad order, he had to knock open four or five crates to make one fit for a first-class hotel. I apologized for putting him to so much trouble, sent my agent direct to the hotels and took orders for all I could supply at $\$ 3$ a crate.

Once more I smiled at the mental reflection of my eagle eye and massive brain and fell to pitying my neighbours.

The new arrangement went forward well. I had shipped a thousand dollars' worth of melons and was figuring out the gross earnings and the net profits and planning great outlays for the following year.

A drought struck us, killed all the old vines in a few days and ripened prematurely every melon in the three fields I had planted for succession. They were not fit to eat. I cancelled the hotel orders, bought some hogs and fed them on thirty acres of cantaloupes, that cost me $\$ 2,000$ in cold cash. 
I retired from the trucking business, and decided that hay was good enough for me.

I built a big hay barrack and put in a trolley fork and seeded the farm in peas, clover and grasses.

In six weeks after the barn was built, a storm blew it down. I cheerfully rebuilt it.

We jammed it full of pea hay in one end and timothy and clover in the other. Besides, we had every other barn full and some stacked in the field. At last, I saw daylight. The hay under cover was selling at the barn door for enough to pay all expenses and give me $\$ 1,000$ in a dividend. Again I shook hands with myself and wondered why the farmers of Gloucester county didn't have sense enough to raise hay. When I opened the big new barn to sell the first load out of the pile of ton on ton where my profits lay, I found it had rotted beneath the surface. It cost me fifty dollars to clear that barn of hay.

Then an epidemic of a strange horse 
disease that no veterinary surgeon ever saw or heard of struck us, and carried off $\$ 500$ worth of farm horses in two weeks.

I had never believed the wild stories about the modern negro farm labourer in the South till I tried it. In three years I've hired over one hundred negro farm hands and discharged all save three of them, who are firstclass men. I tried patiently to teach one I kept six months to do a few simple necessary things with modern farm machinery. At the end of six months he broke three mowers in one day on a beautiful level piece of clover.

I discharged him, and that night lost twenty dollars' worth of harness out of my barn.

Large groups of my African neighbours keep horses, dogs and children and yet are opposed to a strenuous life of systematic and constant labour.

I'm now spending cheerfully $\$ 500$ on 


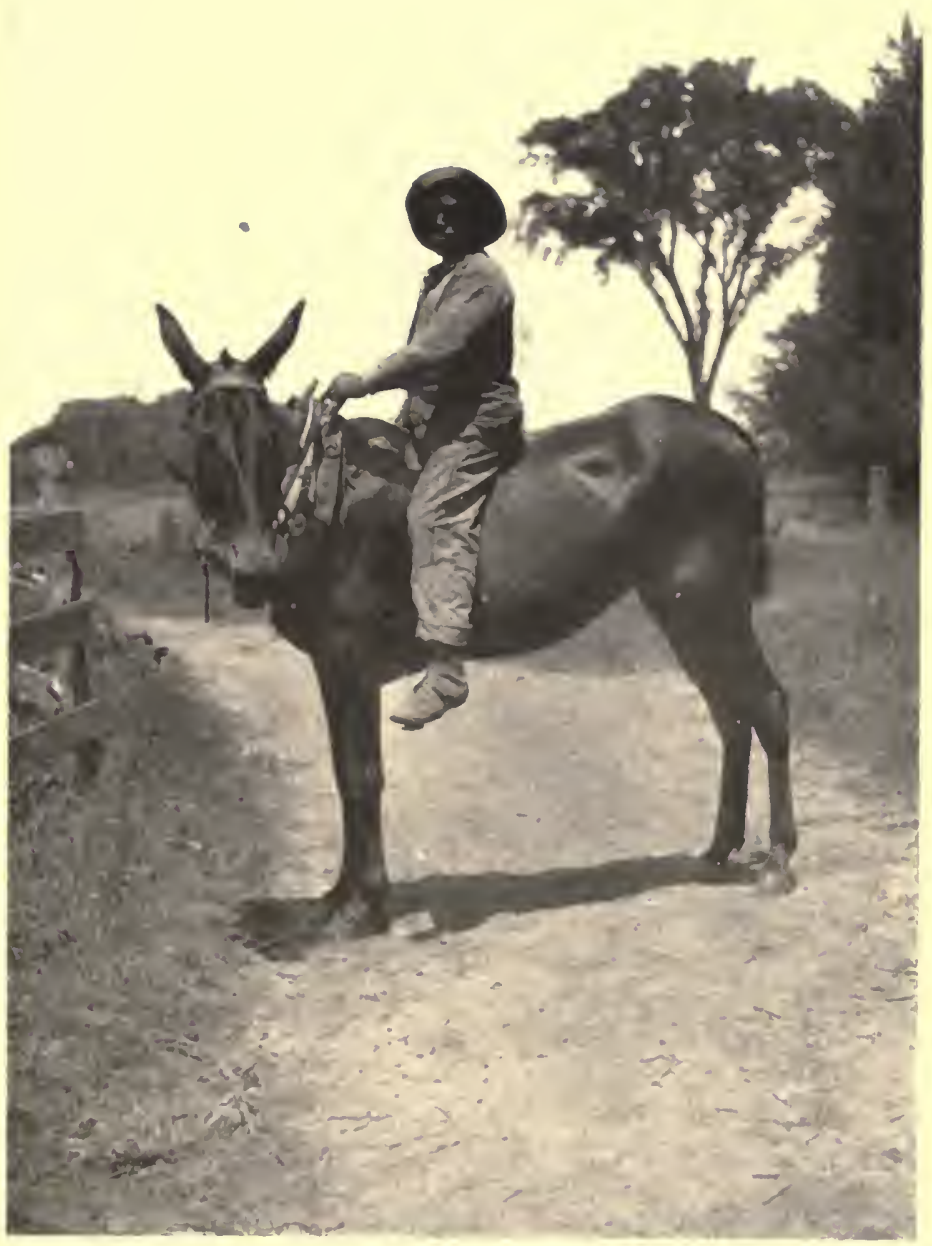

THE INEVITABLE 



\section{Some Sins of Nature}

fences. I've determined to raise cattle. Will the fever strike them, I wonder? Who knows?

The experience of these three years, in which my total farm losses have reached about $\$ 7,000$, has given me a feeling of tenderness and sympathy for the farmer I never had before. Who can measure the sum of his anguish through the years as he watches the fleeting clouds in the brazen heat of summer and sees no sign of rain, knowing that every moment of that heat is burning to ashes the hopes he has cherished for his loved ones?

With me farming is a dissipation. I am willing to spend my hard-earned money in this game with Fate. It is gambling. The cruelty and sheer brutality of Nature fascinate me-she who has no ear to hear, no heart to pity, no arm to save the weak, knows no conventions of morals or qualms of conscience, breeds and kills by the million while her eternal life rolls on forever. 
But when I look on a little check sent in for a year's struggle, not large enough to pay for the labour expended, when I look on a dead field parching in the August sun, gaze on the ruins of a storm-wrecked barn, see men dumping ton on ton of spoiled hay, or gaze on the carcass of a horse as they drag him away for burial, and think of what this means to a man whose bread depends on it, the pity and the pathos of it all overwhelms me. Back of the serene beauty of Nature I see her tragic cruelty. Man must obey her laws or die. Alas, how few of us know her laws!

Yet there is something supremely fascinating in this fight with sun and storm, earth and air, their mysterious moods and myriads of swarming lives. Man has not been baptized into the life of our planet until he has felt the challenge and tested the sinews of his soul in this combat.

There is something still more stirring, too, 
in the great human struggle pending between the American farmer, the most intelligent, aggressive and powerful Producer in the world, and the forces of Distribution. At present the distributer gets it all in the long run.

It requires more brain and moral fibre, muscle and soul patience, to successfully run a large farm to-day than to conduct any other enterprise of modern civilization.

And town-bred dudes have been known to sneer at "hayseeds." 


\section{CHAPTER VII}

\section{The Shouts of Children}

I believe it is a crime to rear a child in New York city, or any great city. The man who is imprisoned in this living tomb by business, may plead a fair excuse, yet it is none the less a crime.

It is a physical and spiritual impossibility to rear a normal human being under the conditions which surround child-life in the modern city. His earth is merely a huge cobblestone with asphalt patches. There is no sun or moon or star. Day and night are one. The seasons disappear. Artificiality is the rule, and Nature becomes a synonyme for $\sin$.

I shall never forget the sight of five hundred city waifs I ran into one hot July night 
as I was hurrying through the car shed of the Pennsylvania Railroad to catch the train for my home.

A philanthropist had given a mission society the money to send these five hundred poor children, who never saw a green field or sat beside beautiful waters, out into the country for two weeks. Poor little old wizen-faced men and women, they didn't know how to laugh or play! If they had been going to a funeral, they could not have been more serious. The word country had no meaning for them.

Who can measure the tragedy of these millions of tramping child feet crowding one another into the grave without one glimpse of this wonderful world through which they have passed?

I do not know of a single man of any force in modern civilization whose character was developed in a great city. President Roosevelt is the only man I can recall of any 
world prominence to-day who was born in a great city, and he became a man because he got out of it, and put himself in touch with Nature.

My children were prisoners in New York. In Old Virginia they find life and freedom. There the doctor came every week, here once a year is enough. We have no signs to "keep off the grass." The lawn is theirs, and on its open greensward or beneath its spreading elms and oaks every game that can tempt a child's heart they can play from year's end to year's end.

Here they learn to watch for the first signs of life in spring.

We have a boy whose eye discovers the first ripening strawberry, cherry, raspberry, melon and vegetable. Long before we think of looking, his keen little eyes have found them, and his swift bare feet come bounding to his mother as he holds the treasure aloft in triumph. 

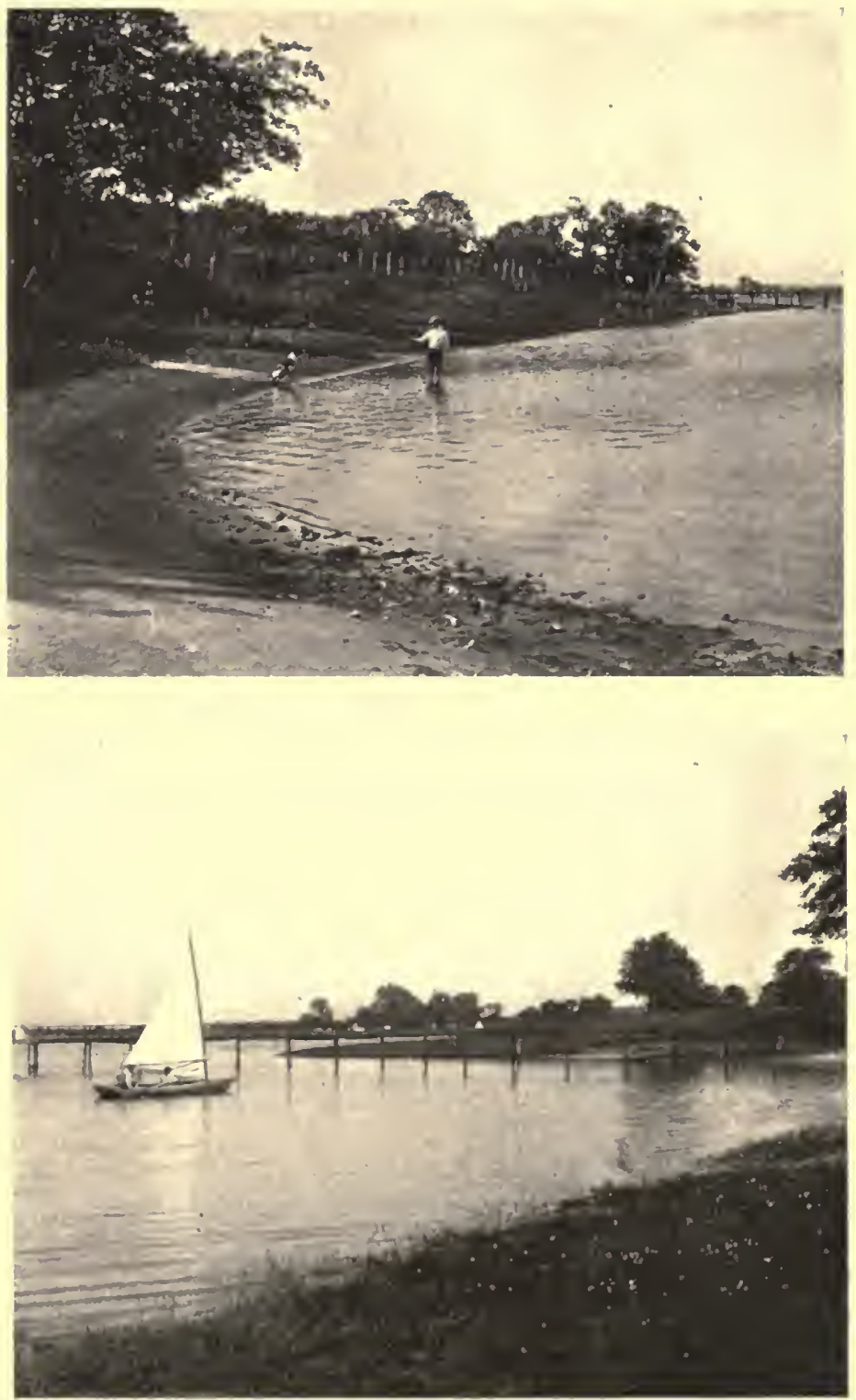

"WE HAVE A BEAUTIFULI,Y CURVED SAND BEACH ON THE LAWN" 

The whole round of country life is a thrilling daily drama for a child. When tired of play he explores the barn in search of hen's nests, and finds them in the most unheard of places, sometimes under the floor, sometimes in the hay rack far up near the ceiling. He has a duck house of his own at the barn, shuts his ducks up every night and keeps them there till eight or nine o'clock in the morning to be sure of their eggs. After Mrs. Duck has laid, he hustles them off to the creek to feed on bugs and worms and fiddlers and fish-eggs.

It is astonishing how many bird's nests that boy can find on the lawn and in the thick hedgerows around the garden and orchard. At first he would rob them all. But it was easy to teach him how much more fun he could get listening to the songs of mockingbirds, watching them sit and hatch, feed their babies and teach them to fly, than by breaking up their nests. Now 
he guards these nests with jealous care. The mockingbird, the wren, and song sparrow, the redbird and bluebird, catbird and thrush, hear his soft footfall without distress. His life has become larger and his heart bigger.

He watched a tiny sparrow build her nest in the grass this spring close beside the pathway to the Steamer's Pier. He saw the first egg and the last, and then the brooding mother, and then the little birds, with growing interest. He kept the dogs and the puppies away and guarded her with zealous care. Just as the bird babies were feathering and nearly ready to fly they made such a big houseful, some beast, a bird of prey, a rat or a crow perhaps, found them. As we went to the Pier at boat time they were all right, and the mother was chirping with pride in the tree above. When we returned, in half an hour, the nest was torn from its perch in the grass and every bird gone. The mother 


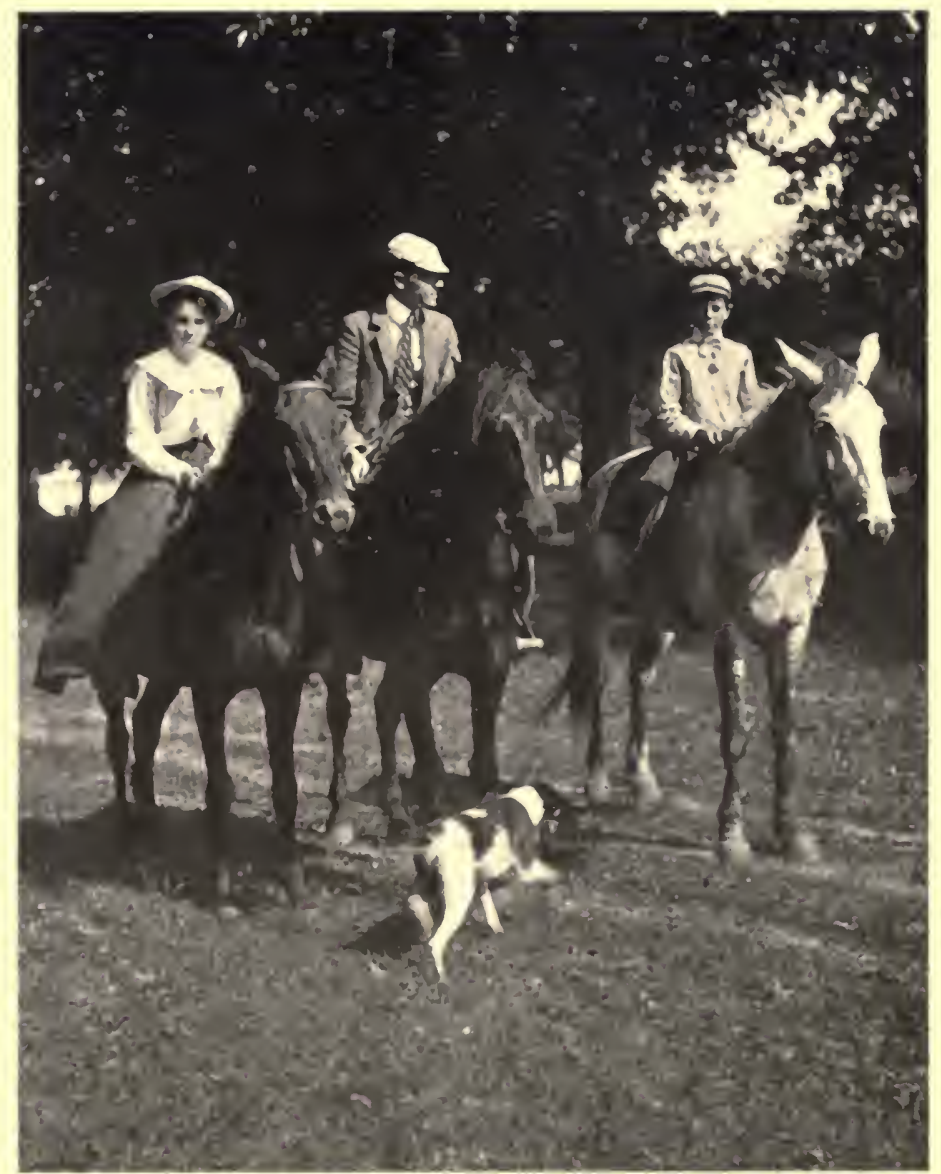

"All HaVE SADDLES AND RIDE LIKE VETEKAN CAVALRYMEN" 

was crying as though her heart were broken. And then a boy's eyes grew dim. Who can weigh the value of such incidents in the shaping of a human soul? How many brass bands, monkeys and hand organs would it take to compensate for their loss?

When the children are tired of the land, the sea calls.

We have a beautifully curved sand beach on the lawn that invites for a bath, and rowboat and sailboat are always nodding their friendly challenge tethered to their pier. Somebody is always fishing in sight, and the crabs in the water's edge are a standing challenge. The horses and mules, colts and puppies, cows and calves are far more interesting to our children in their daily life than the wild animals of a circus. Daily life is a continuous performance in which the child is both audience and ringmaster.

My riding mare's last year's colt I gave to my little girl. When she went to boarding 
school, in every letter home were anxious inquiries about her pet. It is her special joy morning and evening to feed and curry and brush that colt. The first thing she did when she got home was to spring from the carriage and throw her arms around his neck. She is now profoundly considering the problem of whether she will make a riding horse of him, or break him to shafts, or both. All three of the children have saddles and ride horseback like veteran cavalrymen. We think nothing of sending our ten-year-old on the fleetest saddle mare eight or ten miles on an errand.

They love the handsome thoroughibred cows, too, watch their calves grow from fluffy wobble-legs into big capering yearlings, and soon learned that one breed of cows do not give sweet milk and another breed buttermilk.

The puppies, perhaps, interest children more than any other animals. I suppose 


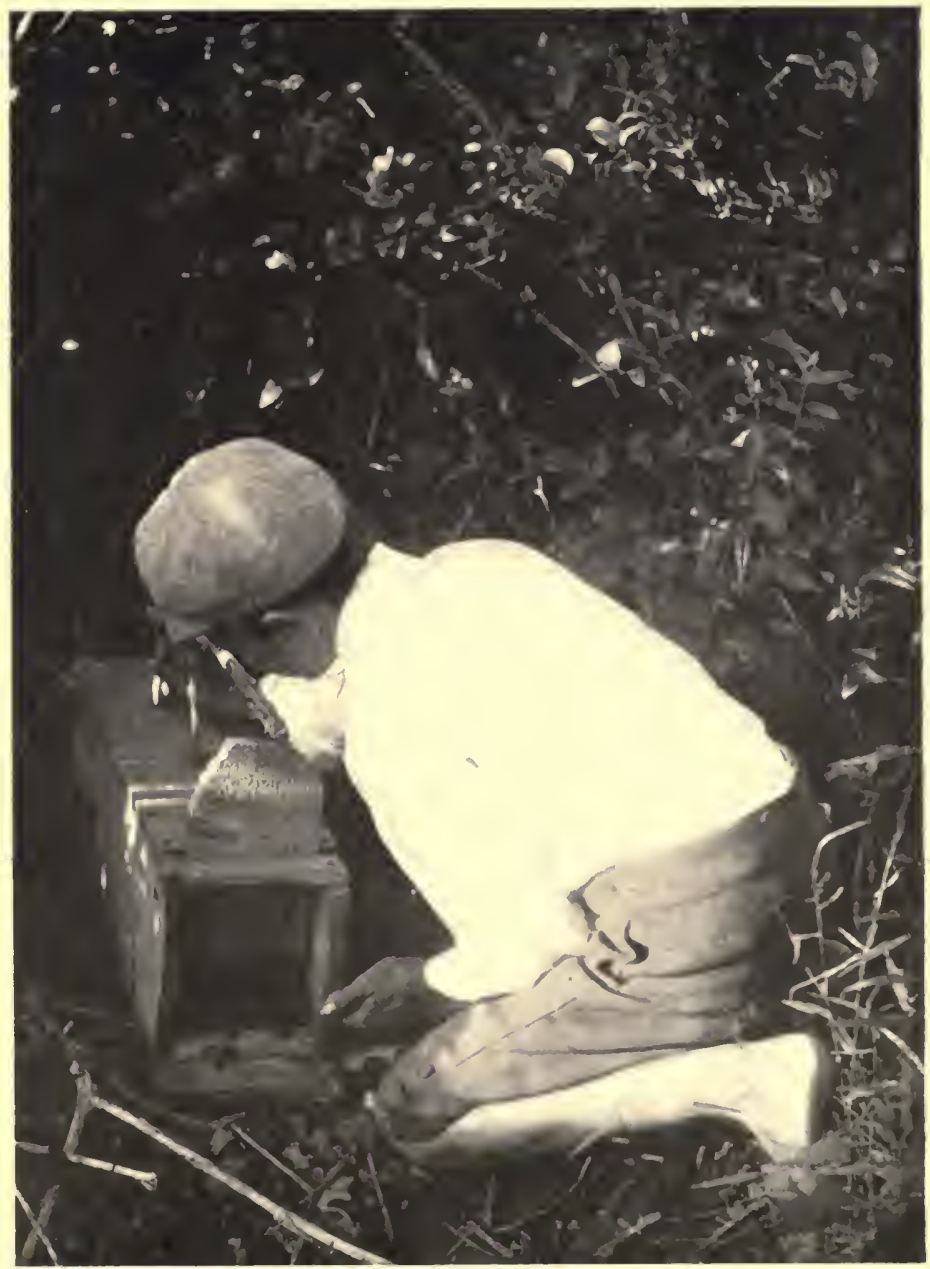

"ANOTHER PLEASURE OF MY BOYS TS THE WOKK OF THE TRAPPER" 

this is because puppies are so closely kin to children in their thoughts and ways. With them life is all play and fun and mischief.

Two pups can think up more mischief in a day than two children. One of them will be quietly sleeping in the sun, and the other one, browsing around the yard, will suddenly discover something of immense interest. $\mathrm{He}$ runs straight to his sleeping brother, wakes him, tells him about it, and off they go. A pup needs more whipping than any animal I know, if given the open lawn and field in which to grow. He will chew everything in reach, including chickens, ducks, turkeys, and especially sheep.

I've lost two sets of puppies in the past year on account of sheep. A sheep is the most tantalizing thing that ever looms on the horizon of a dog's life. When a sheep sees a dog, he exhibits first a most intense curiosity, lifting his head high in the air and standing stock still. When the dog makes a 
movement forward, or sidewise, with or without any idea of further acquaintance with the sheep, the whole flock break and run as though the devil with an army of fiends were after them. The temptation to chase is simply beyond the power of any mere pup to resist, if he has passed the age of chewing gum shoes. I don't blame them. If I were a pup, I'd chase sheep.

When a pup once gets a taste of this royal sport there is but one remedy, and that is to cut his tail off just behind his ears, or send him to the city. The first remedy is less cruel than the second, and is soon over with. A puppy fairly grown, with the sheep habit well fixed, has been known to kill fifty sheep in a night. He never eats them, but just kills for the fun of the thing.

I paid my neighbour for four lambs one of my pups killed, and on the fifth occasion the farmer happened on the ground with a shot gun and persuaded him not to do so any 


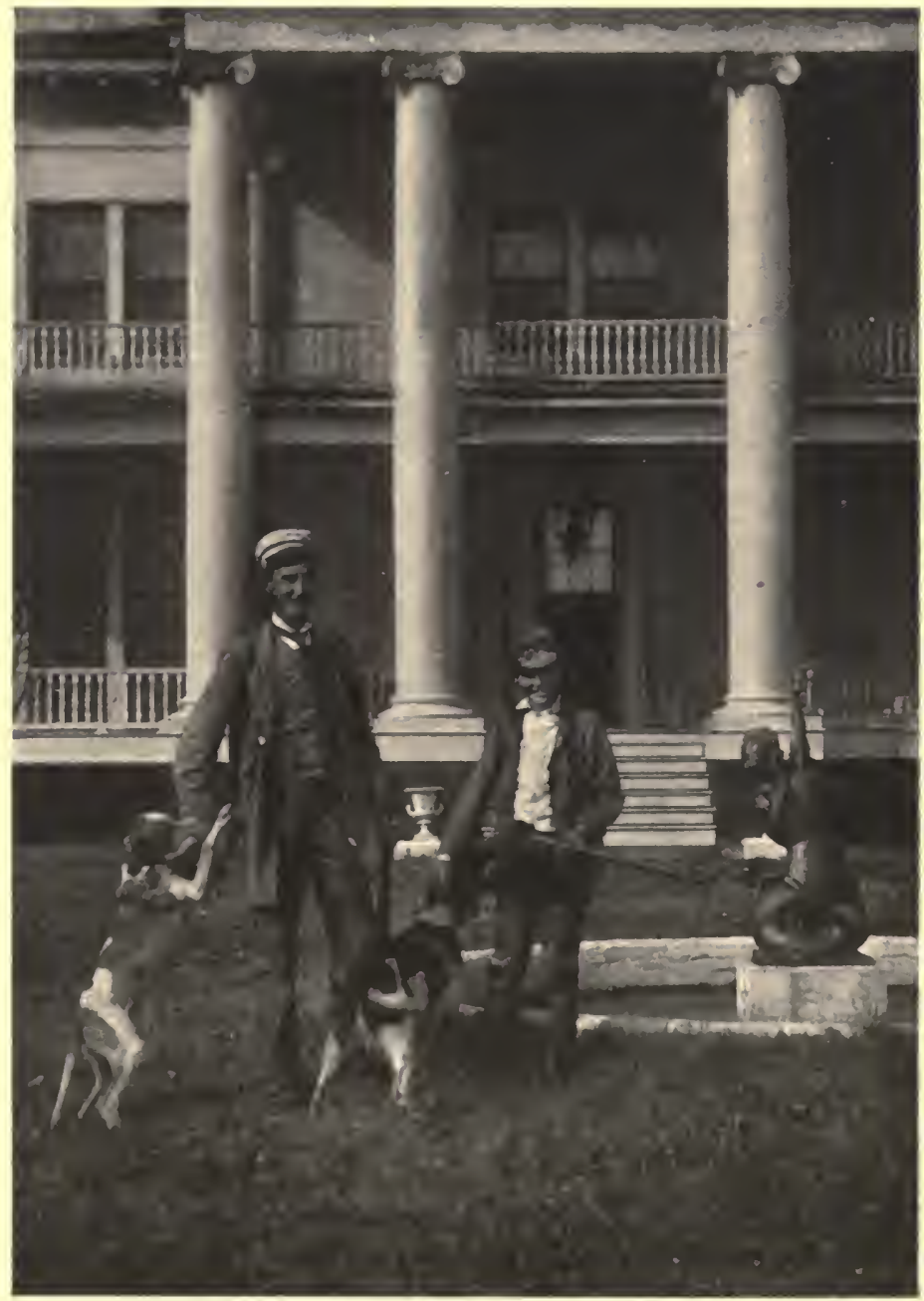

"I BELIEVE IN THE GUN FOR A NORMAL BOY" 

more. I mourned, but couldn't complain. I don't like sheep. They trouble dogs. I bought a small flock for my lawn just to train the pups. Becky and Bob's family have grown up from the cradle with these sheep and never molest them.

Another pleasure of my boys is the work of the trapper. The moles infest the lawn and would plough up whole acres of grass but for the boys and their mole traps. They catch one nearly every day when they get troublesome and soon thin them out.

Rats kill young chickens and birds, just as a puppy kills sheep, for the fun of it. A rat killed and carried out of a brooder seventy little chickens for me once within forty-five minutes. A rat got into my neighbour's brooder and killed over a hundred chickens in one night and left them in great piles. A steel trap set the next night caught him.

But of all the traps a boy ever sets, none gives him quite the keen delight of an old- 
fashioned rabbit-gum set skilfully in a path along the hedgerow or in some deep sheltered glade.

I believe in the gun for a normal boy. I teach my boy to shoot with me when he is so small he has to kneel and a number twelve gun kicks him flat on his back. It's funny to see a youngster pick himself up and declare he "didn't feel it at all!"

Narrow and poor is the child's life who never roamed the fields alone with his dog and a gun on his shoulder. He may make a man without it, but he will not have an equal chance with the boy whose heart has thrilled with the elemental joy that links him to the habits and instincts of four thousand years of human history. The first man was a hunter, a trapper and a fisherman. When man ceases to care for these things, or decries them, I fear that he is either sick, a fool, or both.

It is not true that it makes him cruel or 


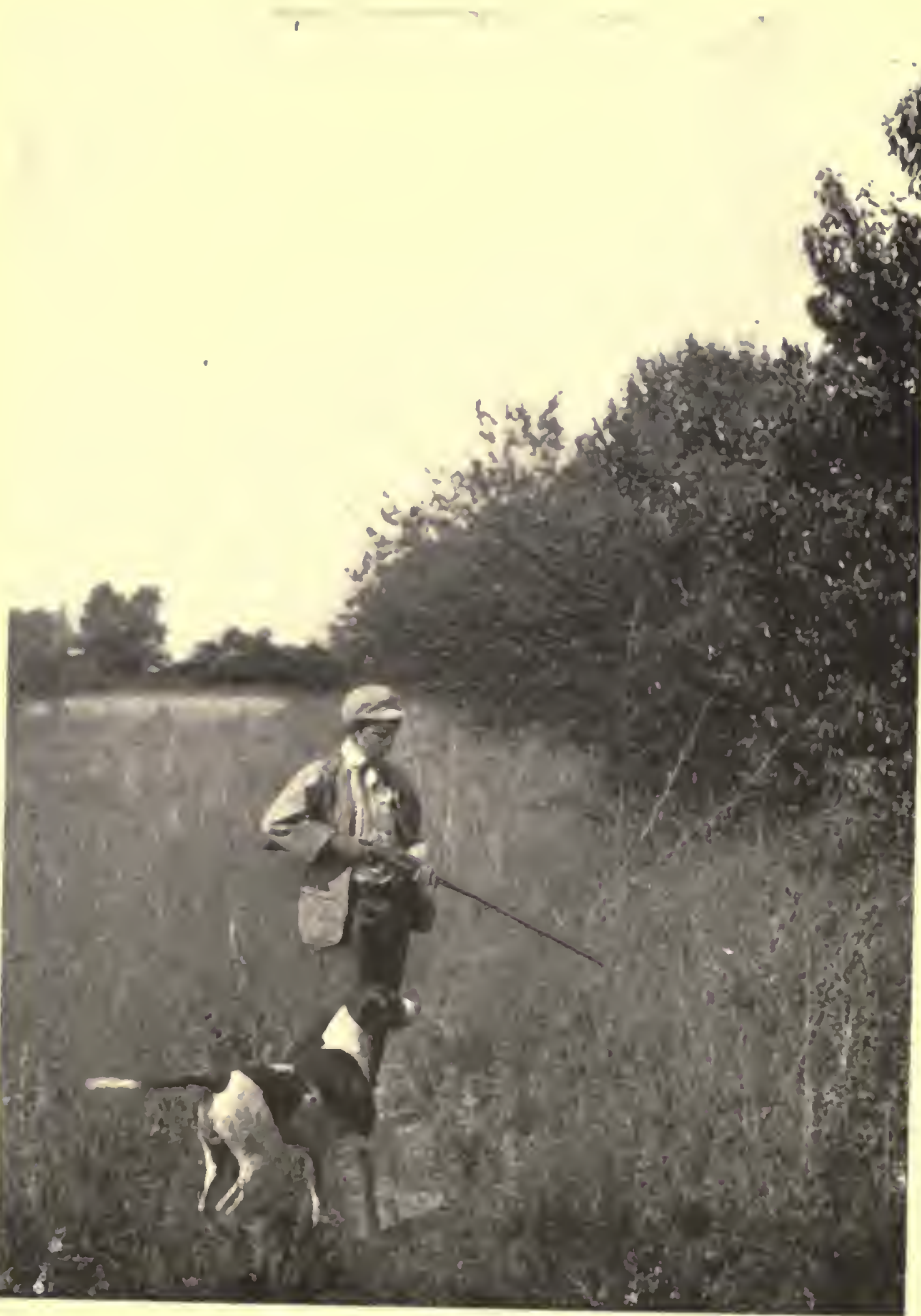

"THE FIRST MAN WAS A HUNTER" 

selfish. Upon the other hand, its effects are just the opposite. He draws close to Nature, learns her laws, and feels the sweep of her elemental life. He kills only what is fit to eat and needed for food. Every element of his character is strengthened by the care, skill, patience, judgment and zeal with which he follows game. Such boys rarely commit crime or display mental weakness. They make strong, clean, sane, wholesome men. 


\section{CHAPTER VIII}

\section{First Lessons in Life}

If I had exchanged my New York brownstone house for a log cabin in the woods on the shores of the Chesapeake it would have been a good trade, if the boys could have had boats.

A boy who learns early to handle a boat has achieved more in education than he who graduates at the head of his class in the city high school.

A boat teaches him the first lessons of life-Law and Obedience-in vital ways. You can talk about Law to a boy hours and hours. It goes in at one ear and out at the other. The fact is, few of us ever learn things in the abstract. We rarely learn anything until Nature raps us over the knuckles and calls our attention to it. 


\section{A boat says to him:}

"Keep in harmony with the Law and I am your swift and willing servant. But if you take your hand off that sheet in a gale, or forget to ease my sail to that cat's-paw in the wind, I'll dump you overboard."

A boat never talks for the pleasure of hearing her own voice. She means it, and it is not necessary to repeat it. One ducking is enough.

The love which a boat inspires in a boy is not quite like any other. It is more complex and broadens his mental and spiritual horizon in proportion to its complexity. He may love a horse, or a mule, or a dog simply for his own sake.

A boat inspires all this and more. $\mathrm{He}$ soon learns that a boat has a soul born of the union of Labour with Nature. Though a boat is made of wood and nails and rope and cotton, the putting together of those pieces by human hand and brain gives it the im- 
press of character which reveals itself the moment she is afloat. Boats are good or bad, tricky or true, just as animals and folks.

Sailing on the river one day with my tenyear-old in his boat, we passed another boy in a narrow cranky-looking craft with a big ugly sail. He was a poor youngster, a cook for some carpenters near by. But the salutes between them were given with all the deference of two ocean captains in midAtlantic. I asked my skipper what was the name of his friend's craft.

"Hell," he answered.

"What?"

"Yes, sir, 'Hell'-she's so tricky."

A boy learns to love or hate a boat for its individuality just as he does man or animal. This love for the boat rouses in him reverence for Nature in her larger life.

$\mathrm{He}$ learns that winds and tides have souls.

$\mathrm{He}$ must study their temper and moods. The face of the water is ever changing from 

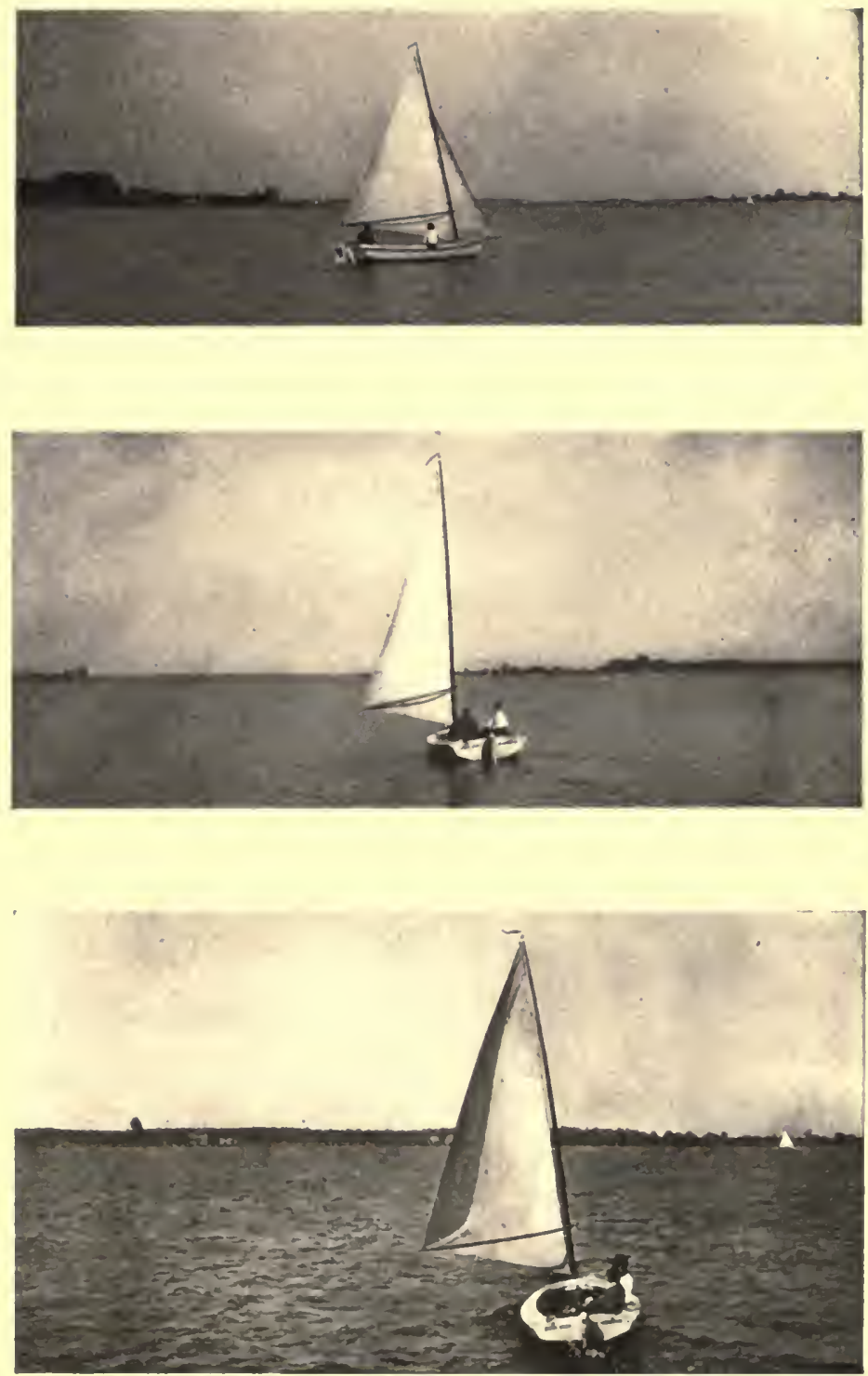

"HE LEARNS THAT WINDS AND TIDES HAVE SOULS" 

laughter to tears, from joy to anger, and with each breath speaks a new message. He must listen. The boat compels him.

The tides speak with authority and eternal mystery. With never a break they ebb and flow twice each day. He must know their hours and plan his life in harmony with them. The fish and crabs obey their laws. He must know whether it will be ebb or flood when he starts home from a day's outing, or he will miss his supper. He must figure the height of the tide to cross a bar and get back to his channel, and must know the hour of high water and low water, the day he hauls out his craft to scrape her bottom and paint her with copper. The tide is his ship's railway and the beach his drydock. He must study the humours of the tide and interpret them. When the tides run unusually low he knows the wind is blowing strong off shore outside and a storm is brewing from the land. When the tide comes rush- 
ing in and piles up its flood to normal reach two hours ahead of time and keeps on rising higher and higher, he knows an easterly storm is sweeping in from sea and makes things snug for its coming. Their everlasting mystery tantalize him with a thousand vague questions about the Power back of their measureless tons. Early he learns the lesson of Reverence in the presence of Mystery.

A boat is a specific for conceit.

When a boy reaches the massive age of thirteen and begins to instruct his father and mother on the conduct of life and the meaning of things, give him a boat and turn him loose in tidewater. He may get wet, but he will be saved early from many afflictions.

I told my boy one day not to venture too far in the wind and tide of the hour from the yacht in his little sailboat. He waved his arm to me in lordly gesture and informed me he could sail her anywhere in sight and get 
back all right. I said nothing and let him go. An hour later, I came out of the cabin and went ashore in the naphtha tender for supplies. The wind was blowing a spanking breeze and the tide was running with the wind like a mill-race. I saw my omnipotent young navigator off to the leeward a mile, anchored, and a distress signal flying. I ran the launch within a quarter of a mile of him, but paid no attention to his frantic gestures for help. I passed on to the shore and an hour later returned. Again I passed him waving his arms and bellowing for a tow. When I got back to the yacht, I took the megaphone and asked him why he didn't come in to dinner. The wind was against him and no words from him, of course, could be heard, but the rapidity of his pantomime explanation of the impossibility of lifting his anchor in the terrible tide or making headway against it, would have been luminous to a wooden Indian. I allowed him to think 
another hour and then sent the launch to tow him in. He was quiet and humble for twenty-four hours.

Last summer that same boy brought his mother home through a wild, stormy night, over miles of coaming seas in a naphtha launch. He sat quietly in the stern, ran the engine, and steered the boat without a compass over twelve miles of black, crooked, foaming channel without once running ashore. He was only fourteen and his mother is a good sailor, but more than once the winds heard him say with quiet authority:

"Come, come, Mamma, don't be silly; there's not the slightest danger."

Next morning his mother looked at him long and tenderly with softened eyes. She had not met him before.

There is nothing like a boat to develop a boy's executive ability, and his self-reliance within the limits of reason. Watch him 


\section{First Lessons in Life}

skilfully beat his craft to the windward, and you know he is learning one of the first secrets in the deep-seas of life. Then see him round the bend in the channel, ease off her sheet, and lean back with a smile as he flies before the wind taking his girl home, and you know he has felt the thrill of the harmony of Nature and her laws. He has come into a heritage no calamity can imperil and no panic ever destroy. 


\section{CHAPTER IX}

\section{Along Shining Shores}

I hold that Old Tidewater Virginia is the most fascinating spot on our planet. I can prove it by the shorebirds, anyhow.

When the migrating snipe have raised their young in the far South, they come north to spend the summer. Far up in the sky, flying V-shaped, as the wild goose, the curlew leads the way in April. With his keen eye surveying from the heavens the glories of the world, he sweeps over the wild beauty of the tropics, calling now and then his silver trumpet-note of command to his flock.

But when he looks down from the clouds and sees the thousand rivers, creeks, channels and solemn marshes of Old Tidewater Virginia, his voice rings with joy, his wings 
droop with ecstasy, and the whole flock break their long silence with such a shout as the Greeks of old raised when, homeward bound, they first beheld the sea.

Gracefully they circle downward, chattering, calling, screaming their delight. They stop and spend six weeks. They know a good thing when they see it, and they see the world from pole to pole.

The curlew is to the shore what the ruffed grouse is to the woods, has about the same weight of body, and carries the same dark brown-and-black-spotted plumage, until sunburnt on his return in August. His bill is about four inches long, unless he is a sicklebill, when it measures from five to nine inches. The jack-curlew is now the only variety seen in Virginia, though an occasional marlin or sickle-bill make the exception to the rule.

The jack-curlew is the wildest, shrewdest and most tantalizing bird with a snipe's bill 
that ever worried and fascinated a hunter. His eye is as keen as a wild duck's, and his ways past finding out. I have hunted them for ten years in Virginia, and many an evening have I gone home with but two or three birds for supper, while the sky above me rang with their shouts of derision.

I have watched them for days and weeks going in thousands to a certain spot on a marsh at a certain tide. I mark the spot and wait ten days for the tides to get back to the appointed hour. Then, all in readiness, I sneak away an hour ahead of my rival, whom I half suspect of knowing my secret.

Everything depends on the tides. By the calendar, the tide should make high water at sundown. If it does, and doesn't make too high or too low, and the birds don't find out I'm on the marsh by hearing the gun, or from the report of a scout-why, then, I'll get some of them. The hunting ground 
is nine miles wide and eighty miles long, and a curlew thinks nothing of a ten-mile flight.

Two hours before sundown, I reach the ground. I've marked the spot on a marsh a mile wide and seven miles long, surrounded by a stretch of mud-bars and channels at low tide, which melt into a beautiful silvery bay at high tide.

I go in my naphtha launch, following the winding channels, from twelve to fifteen miles, to get two miles as the crow flies. But I must get to the marsh, put out my decoys on the exact spot on that seven-mile stretch to which the birds are coming, and hide before the first bird appears, and this must be done before the tide rises. The curlew are now scattered over the vast reaches of this eighty-mile bay, eating bugs, worms and sand-fiddlers on the mud-bars and on the creek banks.

I leave the launch at the head of the chan- 
nel and drag the hunting dink with guns and decoys over the mud-bar to the marsh.

I take an hour to locate the right spot. I'm dead sure of the place they went the last run of tides, but, if the conditions of weather differ, they may change their notion with the change of wind and stop a mile below or go a mile farther on, and to miss their track five hundred yards is to miss them five hundred miles. They will not listen to a call in their great flock flights on this run of tides.

At length I select the place in which to cast the fate of the day. I set the decoys in the short grass of a bald high place on the marsh, exactly where I believe they will assemble in grand conclave to sit out the high water. A hole is dug with a spade just deep enough to lie flat on one's back and hide below the surface of the ground, and tall green grass is cut and stuck carefully around the hole until it looks like a hundred other clumps of grass.

The calico birds begin to come in long be- 
fore a curlew is seen or heard. I take a crack at them to get my hand in for Mr. Jack Curlew. The calico plover is a fine practice shot, for he is swift as lightning unless he sees fit to decoy perfectly.

At last the mud-flats are all covered and the hour has come for the flight to begin. I am on the lookout for a scout. The curlew send out a scout to survey the ground to which the great flocks are coming. If things look suspicious, he goes back and reports, and they change their flight ten or twenty miles in another direction.

No scout appears. I wait an hour and begin to grow uneasy. The tide is slow, a westerly wind has spoiled the flow, and not a curlew comes within five miles of me.

I try the next afternoon, and the wind jumps around to the east, the tide covers all creation and runs me out of my hole before I get a shot, even at a calico.

Again, not a curlew came to the marsh. 
They all went to the sand-dunes on Myrtle Island, fifteen miles below. I watched them for an hour. The heavens were streaked with them as far as the eye could reachnorth, south, east and west. I ground my teeth and vowed vengeance. I have but one more day of this run of tides. If they don't come to the marsh the next night, they will not come till the tide gets around again in two weeks.

Again I've baled out my hole and rebuilt my grass blind, and, snugly resting on the rubber blanket, I gaze up at the southern sky, or away over the endless marsh and bay, and wait. My guide has gone a mile with the launch and hidden in the tall grass of the creek.

How still the world!

To the east, I see the dim white line of the ocean beaches, but the wind is from the south and I cannot hear the surf. North, south and west of me sweeps the dark green 

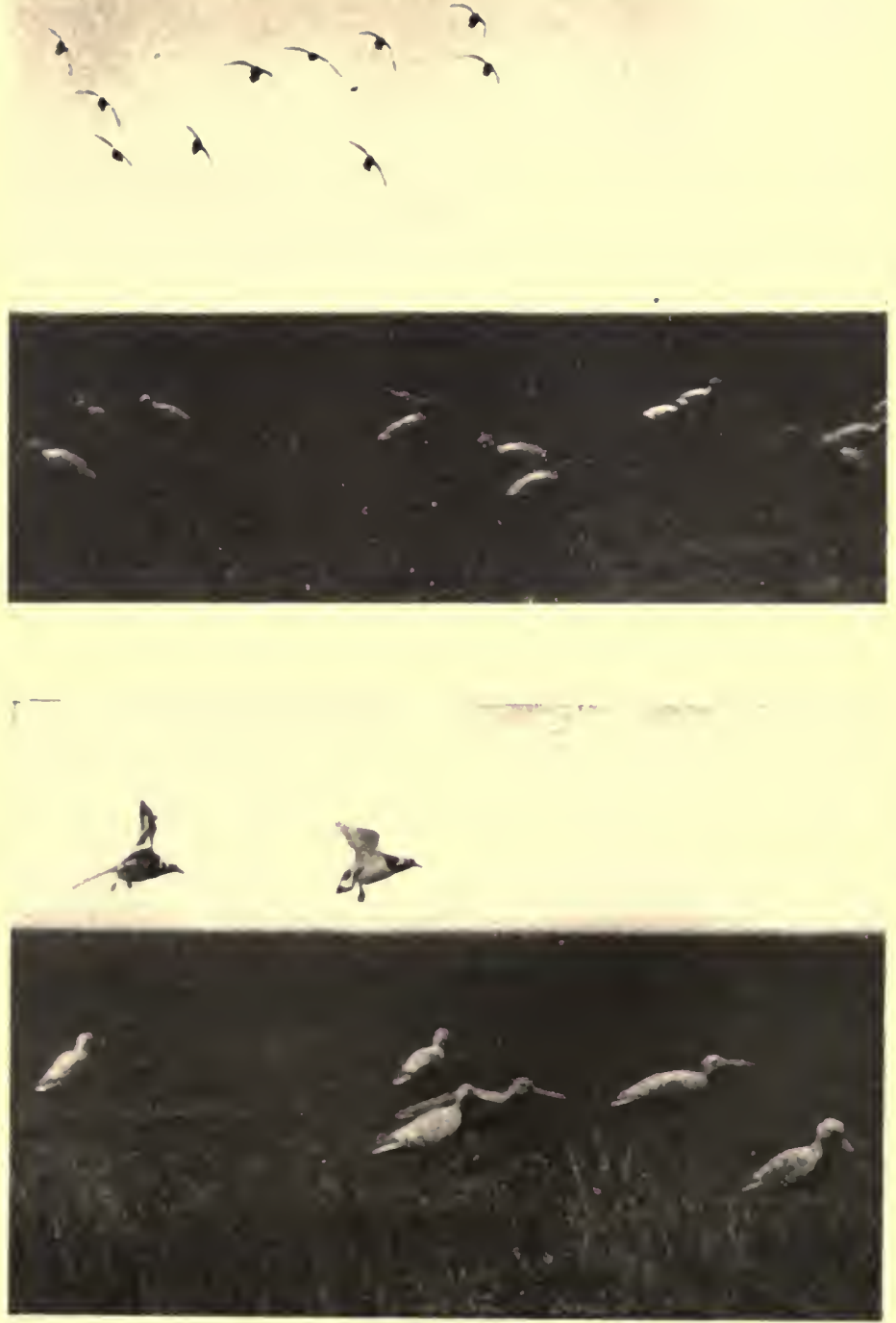

"AWAY OVER THE ENILESS MARSH" 

marsh, until it kisses the sky-line and fades into eternity. I begin to dream of great things. Nothing small disturbs my visionnot a house or man or woman is in sight.

I begin to feel pity for the feathered life I've come to take, when my eye rests on a mother fiddler in the mud beside me, peeping out of her hole to make sure no curlew is near before venturing out for food for her children. I clutch my gun and determine to take sides with the fiddlers.

"A curlew's a mean bird, anyhow," I muttered. "Confound 'em! let 'em come here and I'll burn 'em up! Besides, I've promised my wife enough birds for the table this week."

Suddenly the shrill call of a curlew scout rang over the marsh, and old Mrs. Fiddler cut a somersault to get into her cyclone cellar.

I slipped the safety-lock of my gun and tried to get under my hole in the ground. 
I must either kill that scout or let him go back without seeing me. I tremble with excitement, afraid to answer his call lest I reveal my position. I know he has seen my decoys and determine to keep silent and still as death.

He came high, circled around me twice, and then came straight up behind, about a hundred yards in the air. Just over the decoys he poised, cocked his long-billed head to one side and peered down at me.

I knew he was coming no closer and it was a long chance shot, but I determined to make it before he could jump. Lying flat on my back, I snatched up my number ten and let him have a snap-shot.

He quivered a moment, and down he came, softly, without a struggle, and fell with his'wings spread out three feet on the grass, so close to where I lay that I could reach him without rising.

I picked him up and found a tiny scarlet 
spot on his big fat brown breast. A single shot had taken effect.

He fell just at Mrs. Fiddler's doo1, and left a drop of blood in her front yard. When I lifted him, the fiddler emerged, with three trembling little fiddlers clinging to her skirts, smiled and thanked me. And then, seeing a baby snail toddling slowly along the road in front of her house, she ran out, grabbed him by the throat, broke his neck, tore him into bits with her big cruel claw, and handed the pieces to her hungry children.

"It's the way of life," I thought, grimly. "Life feeds on life; the man on fish and animal; the bird on the fiddler; the fiddler on the snail; the snail on the worm; the worm on the cabbage, and the cabbage on the vegetarian!"

And, when we get down to the last celllife, no eye can tell the difference between the germ that will grow into a vegetarian and the one that will grow into a cabbage. 
And yet the vegetarians put on holy airs, and say mean things about hunters and meat-eaters. I've often wondered what the cabbages, beets, turnips, peas and beans whisper to one another about these people in the still moonlit nights of the spring, when they are struggling to reproduce their kind.

I reloaded my gun and lay for another curlew. In about half an hour they began to come. I found I had missed the spot they had selected for their meeting by about three hundred yards. They were going just beyond my blind, three hundred yards farther up the marsh across a creek. But they were leading so close to my decoys that by vigorous whistling I enticed in a dozen large flocks and scores of small groups. When the sun sank I had bagged seventeen. I went home with a song of victory. I felt I could look my wife and children in the face once more. Only once in ten years did I break this rec- 
ord. Then I had the remarkable luck of having the wind and tide just right and I got to the right place. Then I carried home twenty-six. Fully fifty thousand curlew came on the marsh that afternoon.

We get a few curlew when shooting grayback, willet and plover on the marshes from blinds. But this can be done only in the early part of the season. One shot from a blind is all that is necessary to educate every curlew who sees the performance. No amount of whistle-calling will get him to come in range of a blind again.

At ebb-tide we shoot the grayback, blackbreast, yellow-legs and curlew on the mudbars, where they come to feed on fiddlers and bugs as the tide ebbs off. I have killed a dozen curlew sometimes from an ebb-tide blind.

One never-to-be-forgotten day the grayback came like chickens, and I made a bag of eighty-two on the first of the summer 
season. The grayback snipe decoys beautifully and is the toothsome quail of the shore and marsh.

But by far the most interesting sport of the shore is when the red-breasted snipe come suddenly trooping in from the mists of the southern seas about the middle of May. Ther feed almost exclusively on the mussels of the ocean beaches at ebb-tide. They usually appear about May I5, though their advent varies by a week or so, according to conditions of the spring weather.

I have walked along the surf in the spring on one day without seeing a single red-breast, and have gone back the next morning and found flocks of ten thousand chattering and feeding. They came in the night out of darkness and mystery, and they will go in two weeks, as they came, into silence and mystery.

Where they go the Virginia hunter does not know. Unlike the curlew and grayback, 
they do not stop on their return flight from the North Pole in August. The curlew and grayback come in April and leave the last of May. They spend five weeks in the far North and return to Virginia about July i 5 , and remain till the latter part of August, or middle of September.

Not so the red-breast. He comes in a night in May, gets fat in two weeks and leaves suddenly. $\mathrm{He}$ is not seen again until next spring.

May i 7 we reached the Life Saving Station of Smith's Island, by the invitation of its genial captain, George Hitchens. It was blowing a furious gale and raining in blinding sheets, with the wind hanging steadily on to the northeast.

The birds had not come, the crew told us, but Captain George said they would come in on the wings of the storm that night. At daylight we caught the old plug of a horse from the stable and hitched him to the cart. 
The Smith's Island Light, just over our heads, the greatest light of the Atlantic coast, was still flashing its gleaming message, " 45 ," over the storm-clouded sea.

Within an hour we had reached the bend of the beach, five miles above the station. The tide had just begun to ebb as the sun burst from the ocean through the cloudbanks of the passing storm.

The Captain was right. The birds had come on its black wings. The beach was literally covered with them. We were in rare luck. We were the first on the beach, the first day of their season, and the wind was blowing a steady gale from sea, just the way we wished it.

Hastily gathering some dead bushes and grass from the sand-dunes, we build a scraggy blind, place our decoys on the edge of the receding surf, and are ready for them.

How beautifully they come!

Sometimes they pitch among the decoys. 


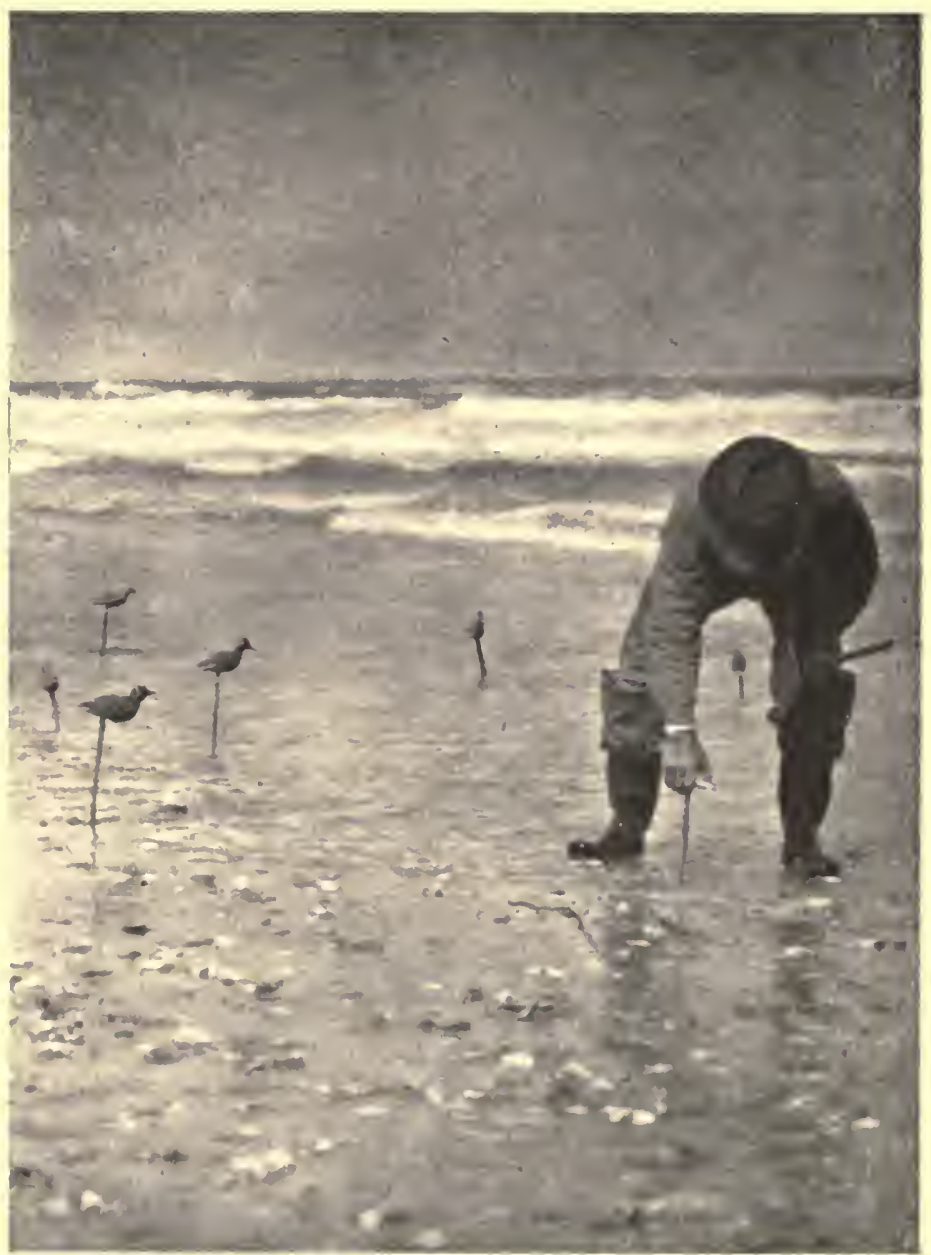

"Place our decoys on the EDge of THE RECEDING SURF" 

First they come in little bunches of two and three, when we take one with each barrel; then the big flocks begin to streak along the magnificent surf and decoy like chickens.

They require no calling. The moment they see our decoys they set their wings in all sorts of fancy shapes and sweep into the happy hunting-ground to share the mussels with our fat wooden birds, whose round shapes no doubt excite their hunger and envy.

Some set their wings in a beautiful bowshaped curve, some drop them gracefully downward, some swing them gracefully upward and drop their legs as they descend.

Sometimes the sky is black with them, their wings set at every conceivable angle. Then it was impossible to choose a good shot in the confusion of a hundred challenging groups. We generally take the poorest chance on such occasions, and perhaps get one bird out of five hundred. 
The ideal flock has from ten to fifteen birds. We wait for the critical moment when they double in their flight after they swing past the decoys. A shot just at this second will often kill a dozen.

At the end of three hours the tide has ebbed off, and the sport is over for the day.

I lie down on the sands, and wait for the flood tide to catch a drum, loath to leave the glorious spot. North and south stretches the long white strip of sand as far as the eye can reach. In front rolls and curls and thunders the surf. Behind me lies in shimmering beauty the mirror of the Broadwater bay, nine miles wide and eighty miles long. There is not a human habitation in sight. Above me the infinite space, flecked now with white, swift-flying clouds-I dream of a world without railroads, or mail-the happy hunting-ground the red man saw in visions of the olden time. 


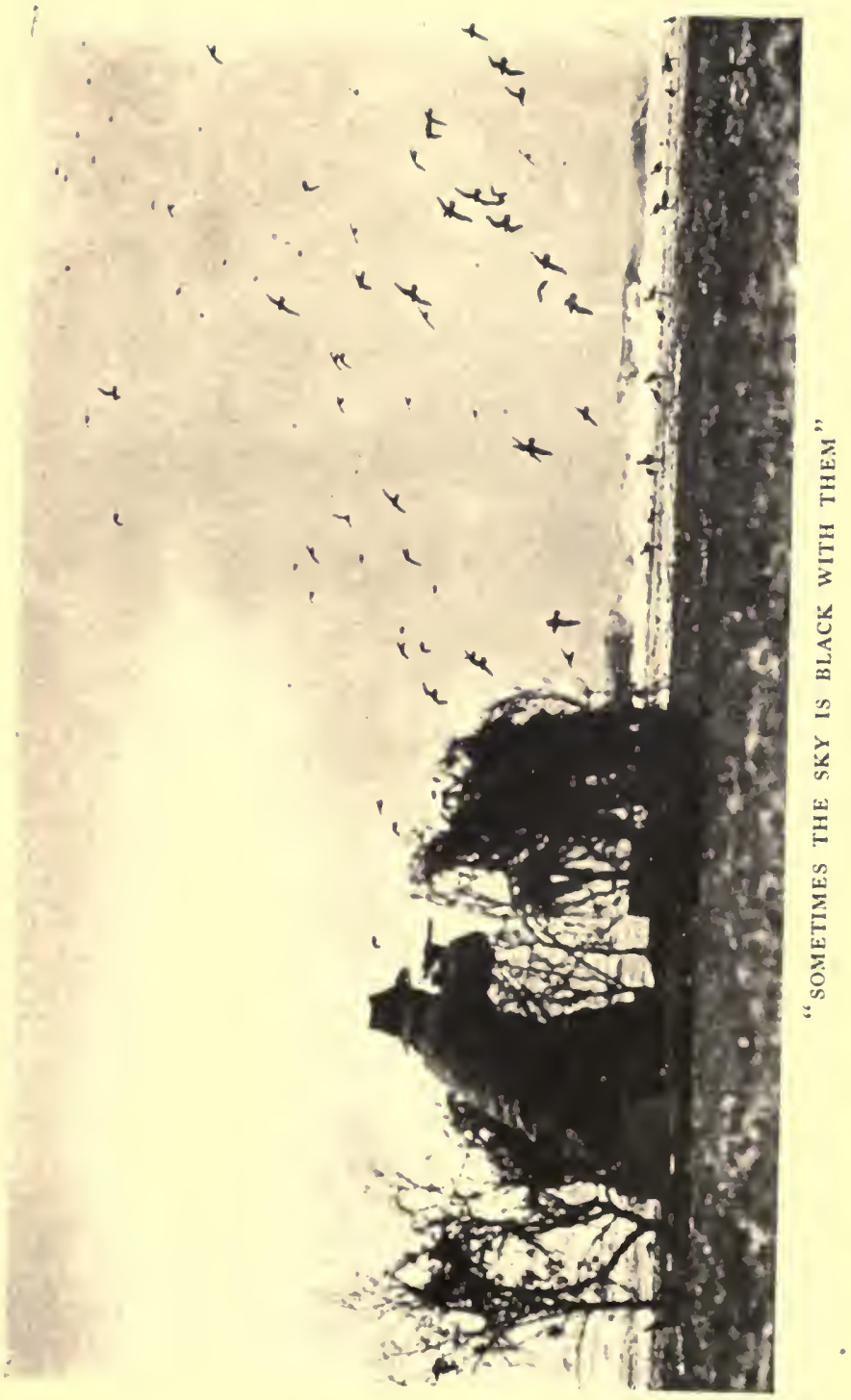





\section{CHAPTER X}

\section{The Breath of the Southern Seas}

The only way to really get out of doors is to push off fifteen miles from shore into salt water. Our planet is a globe of water through which five or six big lumps of dirt and rock project. We call these lumps of exposed earth, continents, and imagine they are the world, when as a matter of fact they cut a comparatively small figure in the total history of our sphere.

The man who does not know salt water is lopsided and undeveloped.

I have known people who spent all their days on one spot of ground on one of these land lumps and thought they could teach the children of men the deepest truths of universal life. 


\section{Has a landlubber lived?}

The sea is our most expressive symbol of the eternal, and the truest test of reality. Fifty cents may pass for a dollar in the interior, but when it strikes salt water, it is worth just fifty cents.

It is so with men.

I shall never forget the overwhelming sense of my own littleness the first view of the ocean brought me. I had graduated from college, and owned a piece of pig-skin on which was recorded the fact that I was a Master of Arts. One day I climbed a sand mountain on the Cape Hatteras reef and looked out over five miles of roaring white breakers beneath whose angry tread I could feel the earth tremble. As far as the eye could reach they came bounding, hissing and leaping after one another. At first I was stunned, then humbled, and at last moved to love and worship. I took off my hat and felt the breath of the Infinite sweep my soul. 
A boat is the only instrument by which man can move over any considerable part of the earth's surface.

When I bought my first boat, and became amphibious, I was an efficient inhabitant of the world. The summer before I had chartered a schooner-rigged sharpie, sailed bravely out of a shallow inlet from the Pamlico Sound, skimmed up the coast fifteen miles to the Oregon Inlet, and tried to come in. Caught by a squall in the act of threading our way through the shoals of this dangerous and crooked channel, we were held there for twenty-three hours between two mountains of breakers with only a quarter inch rusty chain anchoring us to life.

I said then that if I ever owned a boat it should have a wheel at one end of it and a machine to drive it. So I bought a naphtha launch in New York.

We named her the Chattahoochee for the 
memory of the river on whose beautiful banks I made love to my sweetheart. She was a swift and powerful little craft-I mean the launch, of course. For two years we ran her, and, within her sphere, she was ever faithful. After nine years' experience, I am thoroughly convinced that the only safe and reliable power for a small craft (up to twelve horse-power) is this naphtha engine which works on the principle of steam. It cost me several thousand dollars to learn this, but I know it now, and I do not need any further information on the subject.

We sold the Chattahoochee after two years' service for $\$ 850$. She cost $\$ 900$ originally. Then I built a more powerful sea boat on the model of the U. S. Life Saving Surf Boat, decked her over, gave her a nice little cabin with two berths, rigged her with a small catsail and put a 2 H.-P. naphtha engine in her. She proved the best boat for her inches I ever saw. I could go out twenty miles at sea, and 
fish all day without a fear, and if a storm struck us, she came scurrying home over miles of coaming seas like a gull. She cost me $\$ 700$, and I sold her for more than she cost, to build a larger and more powerful auxiliary craft on the same model. Then I made the important discovery that a boat has a soul, and that a fool could not build one. This boat cost me $\$ 1,850$, and five minutes after she was launched I wished to sell her. I had placed in her a so H.-P. gasolene engine of the explosive type.

I worked on that engine two hours every morning before starting, and never went out of harbour knowing when I would get back. She had the devil in her from the start. She wouldn't sail, she wouldn't run under her engine, she wouldn't keep still at her anchor in harbour, and she would lie down in a half sea like a balky horse.

At last I found a man who was looking for that particular kind of engine in a boat of 
exactly her make. I sold him the boat for $\$ 1,200$, a hundred dollars less than the hull cost me, took his note for the whole amount, and gave him the engine.

He has never liked me since.

Then I built the Swannanoa, a model naphtha cruiser, in the shops at Morris Heights. She was 50 feet long, Io feet beam, had four berths in her saloon, a neat galley, and toilet room. She was finished like a piano in mahogany and upholstered in silk and plush. She was a thing of beauty, and in every way a success except that she was too fine for comfort in rough cruising on fishing and hunting trips. After one season in Virginia, I ran her back to New York and sold her for $\$ 4,500$ within two hours after she touched the pier.

The original cost of the genuine naphtha launch is high, but they can be sold at a small loss. A thing is worth after all what other people will give for it. 
I had now served five years as an apprentice at boat building and sailing, and had found out what I wanted and what I did not want. While I have never given up the naphtha launch-I still keep a 4 H.-P. hunting knockabout for short trips and a $2 \mathrm{H}$.-P. for the river-I determined to build a real yacht.

My five years' experience had taught me the limitations of small-power craft, and the Governmental regulations made a steam yacht impossible. I desired to have a boat of ocean-going capacity of which I could be the legal owner and sailing master. A millionaire may buy a steamer and hire a crew of efficient navigators and scamen, but a man is never a yachtsman until he is the sailing master of his own craft and knows the responsibility of giving orders from her deck that may mean life or death.

In no way can a man so accurately ex. press his character and temperament as on 
96

the boat he builds if he has had sufficient experience to understand the language of the sea.

I planned a schooner yacht of oceangoing tonnage, yet of such light draught she could thread her way amid the labyrinths of sand shoals, mud-flats, marshes and creeks that make the home of the wild fowl in Tidewater Virginia.

Five things I tried to express in this boatsolid comfort, safety, economy, utility and beauty. I planned her 80 feet long, 20 feet beam, and 3 feet draught; and the lowest estimate I could get on her in New York and vicinity was $\$ \mathrm{I}, \mathrm{r}, 000$, without sails.

This sum was beyond my purse. I came down to the Chesapeake and found Mr. E. J. Tull, of Pocomoke, Maryland, an efficient builder of merchant work boats. He built her hull. Her iron and brass work I had done in New York, and her sails were made at Crisfield. When she was finished and 
launched she had cost me $\$ 3,500$, and I put a naphtha tender on her davits at an additional cost of $\$ 600$.

The decks fore and aft took 30 feet of her length. I built a cabin over the 50 feet amidships. This gave me head room of six feet six inches, and guaranteed ample light and ventilation for winter and summer cruises in Southern waters. The flush deck schooner gives poor light and ventilation. I placed in her forty-six bull's-eye windows, one row in her cabin walls, and one row in her hull below decks. Her interior is always as bright and cheerful as a house. The 50-foot house gave me on one side of the companion way a triangular toilet room five feet long, and the other side a similar room for wash basin and water cooler. The main saloon is 16 feet square with four seat berths and is lighted by sixteen windows. It is large enough for a sideboard, writing desk, music box, piano, a large dining-table, arm chairs and a stove. 
Next to the saloon cabin are two large state-rooms on either side of the hall, each I $2 \times 8$ feet, containing full beds, writing desk, a case of drawers, a clothes closet and wash basin with running water. Next to these is another large state-room $8 \times 8$ feet and a pantry opposite, $6 \times 8$ feet. Next to the pantry is the galley, $8 \times 8$. Opposite the galley is the refrigerator and the cold storage pantry, $4 \times 8$ feet, and alongside of this the first-mate's state-room opening into the crew's quarters, $8 \times$ r 6 feet. Under the forward deck are the oil-tanks for naphtha and kerosene, the chain lockers and crew's toilet room.

In summer an awning, 8o feet long, covers the entire ship, and iron ventilators are set in openings over the saloon and each stateroom to catch every breath of wind. Her interior is finished with pine paneling painted white, trimmed in gold; and her upholstery is in dark scarlet corduroy. The odd spaces 
are utilized in the construction of eighteen closets and twelve large drawers. Under her after decks are built three water-tanks which give running water in four state-rooms, the wash-room, galley and crew's quarters.

I attained safety in constructing her of the best and the heaviest material. Her outside skin is of 2 -inch heart pine, her ribs 4-inch oak doubled, and her inside skin 2-inch heart pine. Her planking outside and inside is fastened to her ribs with 6-inch galvanized iron spikes. Her crossbeams overhead are 6 and 8-inch heart pine. Her masts are single sticks, the foremast 80 feet and the mainmast 72 feet, and she is rigged with the Chesapeake Buckeye Sharp Sail, the safest and most powerful sail that can be put on a boat for heavy work in winter gales.

This Buckeye rig gave me the most economical yacht that could be built. It costs only $\$ 30$ to put a new set of running rigging on her, and I never hire more than two men 
I00

and a boy for the crew. I pay one of these men, the first mate, $\$ 50$ a month. He is an experienced sea-dog and an expert hunter and guide. The cook, the second man, costs \$16 a month, and a cabin boy, \$8. We can keep her in commission six months of the year at a total cost, including provisions, of $\$ 75^{\circ}$, which is cheaper than we can live ashore.

Such a craft is the most useful boat in Virginia waters a man can build. She will go into more places and do more things than any other boat of her size afloat. She is so powerfully built that she stands up straight on a sand-bar or mud-flat as comfortably as afloat and without damage. We can anchor on the feeding grounds of wild fowl where the tide leaves her high and dry twice a day, and stay as long as we like. She is a powerful sea boat when she drops her centreboard and draws to feet of water, and if overtaken in such a storm at sea that she could not live, she can 


\section{The Breath of the Southern Seas Ior}

lift her board, and in 3 feet of water walk up on the beach and land her passengers in safety to them, if she lose her own life.

That she has beautiful lines I leave her picture to say.

The only weakness of such a craft is that she is not so fast as the full gaff-rigged schooner in the light airs of summer. And yet in four years' cruising in Virginia waters I have never brushed up against any boat of her size of any rig that has been able to keep up with her, though I have never tried her with anything except working vessels.

It is a peculiar pleasure, as well as an elemental education in the fundamental things of life, to fit out such a boat for a month's cruise. It takes her crew of three about a week to fit her sails, fill her water-tanks, coal and wood bunkers, and stock her refrigerator and pantry. We make list after list of the things needed, and when ten miles off shore always find we have left behind some of the 
most important of the little things we are sure to need first. My wife has become an expert at this work with four years' experience. The man who loves the water is thrice happy if his wife has similar tastes or has the adaptability necessary to acquire them. I can safely say that the happiest hours of our married life have been on board this schooner yacht. On her long graceful bow are carved in oak on either side the smiling face of a negro looking at a row of flying ducks, symbolic of her name and habitat.

I was anxious to get the opinion of my sea-dog, Captain George Isdell, on this boat when he first brought her home from her cradle at Pocomoke where she was born in December, I 897.

His face was wreathed in smiles. Such men are always blunt and plain spoken to the point of rudeness when they talk about the qualities of a boat. They find her weak 


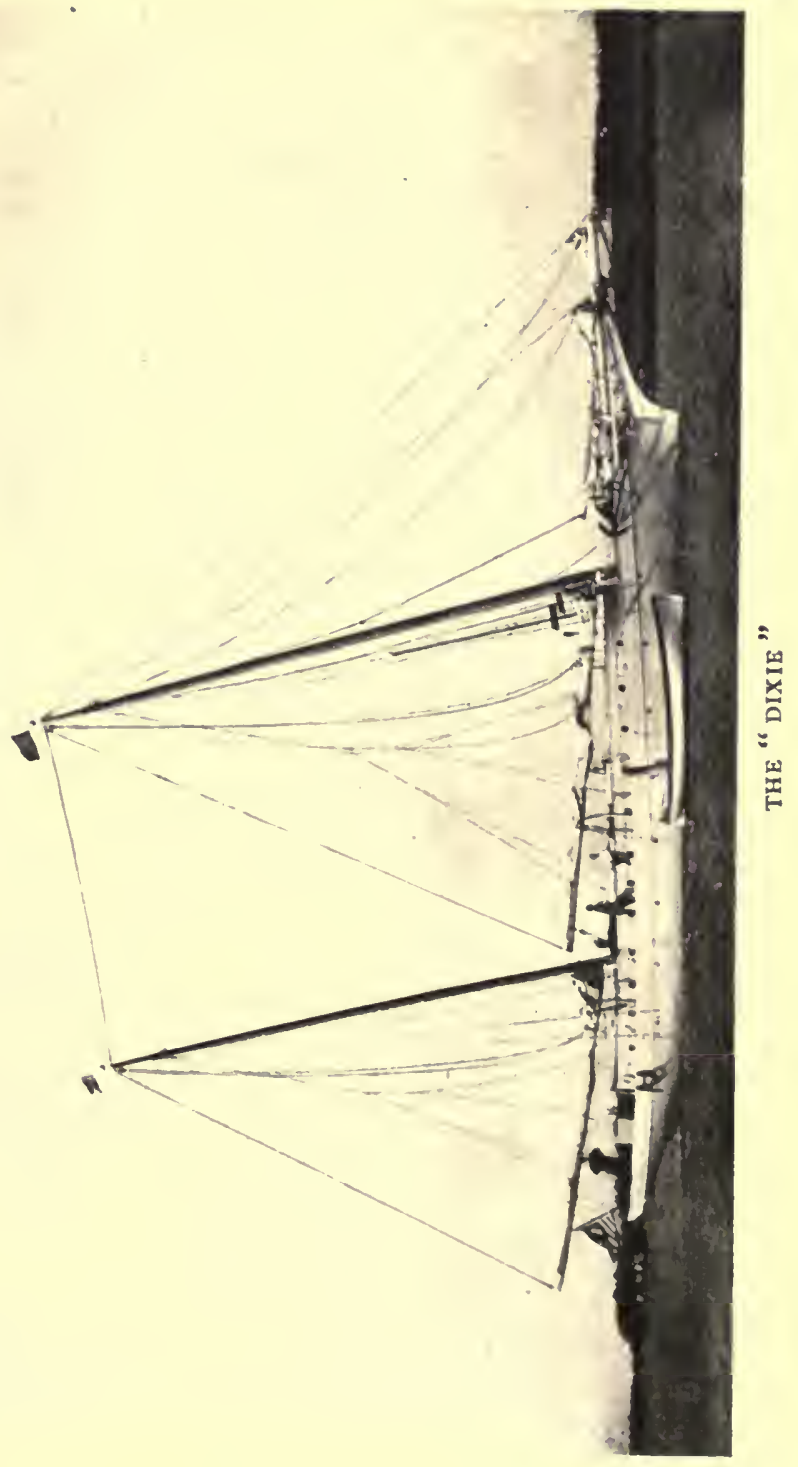





\section{The Breath of the Southern Seas Io3}

spots in twenty-four hours, and tell you with authority what she is worth.

"How is she, George?" I asked as I sprang up her steps the day she arrived.

"She's a Jim-dandy!" he cried with a grin. "She goes through the water slicker'n a eel. She stands right up in a blow and leaves a white streak behind her as far as you can see."

And so I found her.

When all is ready for the winter cruise, and we had said good-bye for a month to the little world on shore, we began to set her big white sails.

I take a hand with the boys clearing her decks and storing everything snug. Her gunning boats and decoys are slung in on deck and her tenders on her davits.

"It looks nasty in the nor'west-we're goin' to have weather," was George's prophecy, as we swung the big forty-foot boom of her foresail up from its saddle and lifted it to the highest reach of her canvas. 
"Well, we'1l hustle and get to the grounds and then let the north wind howl," I replied. "That's what we want for the ducks."

As we swung out into the channel and headed for the Chesapeake Bay, black scurrying clouds from the north came sweeping down and obscured the sun. In a quarter of an hour the bay was a white smother. I heard her new steel shrouds crack as her tall masts heeled over and tested their temper.

"That's only the lanyards finding themselves," said George.

"Do you think we'1l have to reef her?" I asked.

"Na-sir, she don't know it's a blowin' with only them three sails. She wants a thirty-mile breeze to show you what she can do."

And we got it.

She swept down the dark waters of the bay like a great white startled swan, her 


\section{The Breath of the Southern Seas 105}

lower row of windows under water, leaving a white thread of foam behind her that you could see for a mile.

"Time her now between these seven-mile buoys!" cried George, as we flashed by a red can bobbing up and down in a mass of spray.

I looked at my watch. Heavens, how she flew! She was alive, and the wind seemed the breath of her joyous soul. As I held her wheel, I could feel the beat of her heart and the quiver of her nerves. When I moved it, she was as sensitive to my hand as a maiden to the touch of her lover. There is something about sailboats that steam craft can never imitate, something that links them to Nature and makes their movements part of the throb of universal life. The man who has felt his heart quicken to the rhythm of this joy will never forget it, nor prove false to the love born in that hour.

"Now, your watch again!" cried George as we flashed past another buoy. 
106 The Life Worth Living

"Twenty-eight minutes," I answered. "Seven miles in twenty-eight minutes; she's a peach! That's mor'n fourteen miles an hour. There ain't a boat afloat can beat her in a gale."

In four hours and a half we made the forty mile run, crossing the long mud-flats with only the jib set. She swung to her anchor at sundown on the ducking grounds, and when her jib ran down with a crash, a great flock of brant rose with a chorus of protest that rang over the waters like the baying of a thousand hounds. The flock was two miles long and three hundred feet deep and their flight darkened the sky like a storm cloud.

"Never mind, old boys, we'11 give you something to talk about to-morrow if this wind holds to the nor'west," was George's answer to their cry. 


\section{CHAPTER XI}

\section{In the Haunts of Wild Fowl}

We had dropped our anchor in the deep water at the head of a channel in one of the innumerable shallow bays of Tidewater Virginia. We were in the midst now of the haunts of almost every wild fowl that spreads his wings along the Atlantic Seaboard.

The prayer of the huntsman in search of ducks, geese and brant is for cold, stormy weather.

It is impossible to get many wild fowl in mild weather. They will not decoy, but will drift around the bay in great masses talking, laughing, screaming and joking at fool hunters they can see plainly squatting in blinds surrounded by wooden humbug birds. They never come closer than a mile 
in such weather, and what a man says on these days would not do to go in a Sunday School book.

But when a stiff breeze blows and the decoys begin to nod and bob in the water, with life in every movement, then we can fool Mr. Duck and Mr. Brant, stock our pantry for rainy days and make glad the heart of friends in town with the call of the expressman.

I never knew how much beautiful weather there was in winter until I began cruising for ducks and geese. I had an idea before that about half the days of our winter life are bleak and stormy. I have found by nine years' experience that on an average there are about four days in each winter month in which the weather is bad enough to make a good day for ducks. If we get more than four days of stormy weather in a month, fit for good shooting, it is a streak of extraordinary luck. And if one or two of those four 

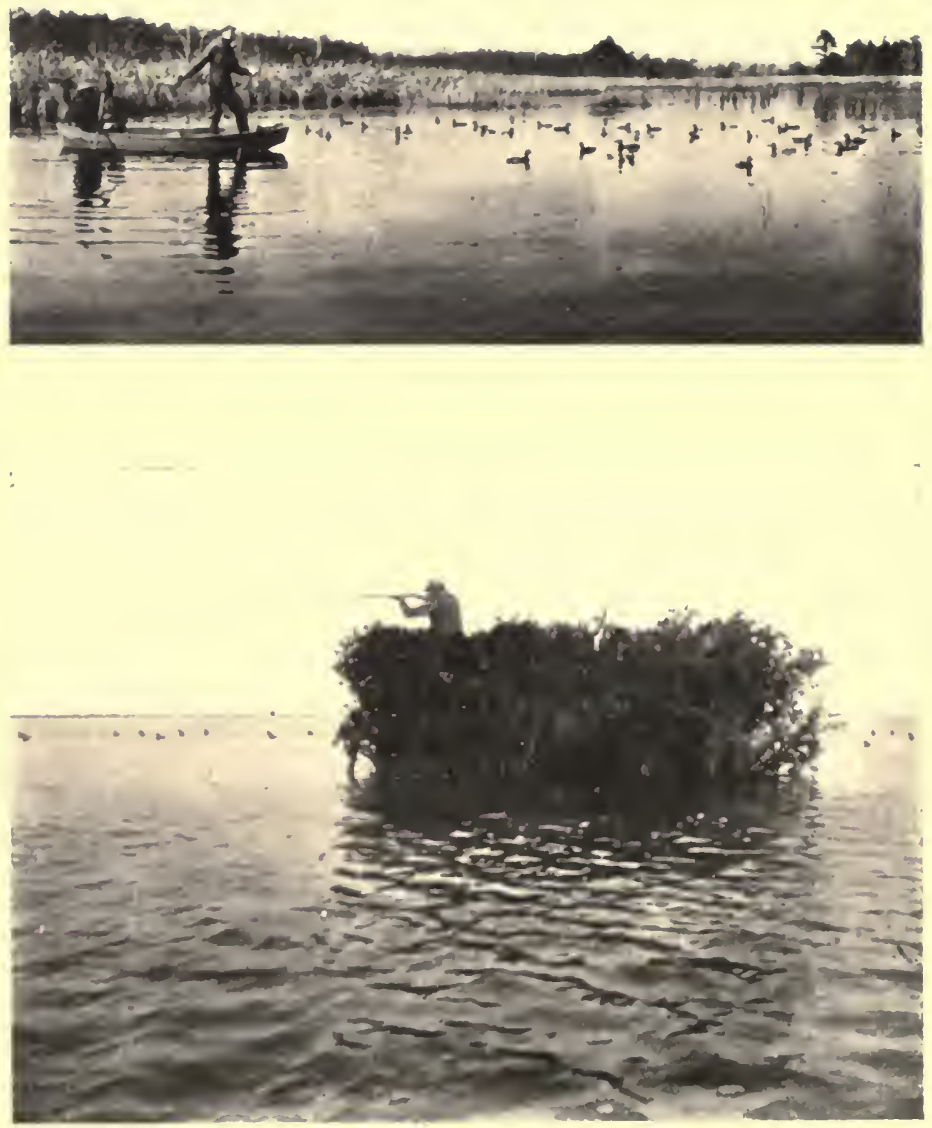

"I NEVER KNEW HOW MUCH BEAUTIFUL WEATHER THERE WAS IN WINTER" 

grand storm days do not fall on Sundays, it is downright rabbit's foot luck.

At night in the snug crew's quarters forward, there is the hum of sportsman industry. The boys are loading shells with number two shot for brant.

The wind is howling a steady gale from the north and increasing the length of its gusts with steady persistence.

"Hear them shrouds talkin'?" cried George with a broad grin. "If this wind hangs on here till mornin' we'll burn them brant. Confound 'em, they're the most tantalizin' bird that ever pitched in this bay. I never killed a one of 'em the whole of last winter. There were no younguns among 'em. It's funny. Some years there's thousands of younguns. But last year I didn't hear the squawk of a dozen, and you can't kill an old brant. This year the bay's full of 'em and we'll burn 'em up to-morrowsee if we don't." 
"I hope so" I replied. "They made me mad enough last winter's cruise, flying all over me, laughing and joking about us the whole month."

"Yes, and they kept it up till they left in the spring. Nobody killed any the whole season. But if we don't have brant for supper to-morrow night, I'll eat my old cap."

When George was willing to stake his old slouch cap with its long visor, that looked like a duck's bill, he was in dead earnest.

"If the wind will just hold on!" I exclaimed, with sad memories of high hopes many times shattered before.

"Don't worry. You'll git all you want to-morrow. It'll be a question whether we can git to the blind. Don't you hear them flaws gittin' longer and longer? That's been goin' on all day. It'll be as long goin' as it was comin' and it ain't got nigh the top yit."

Sure enough, the next morning, as we ate breakfast by lamplight at 5.30 , the wind 
was howling and shrieking through the rigging like a thousand devils.

George looked grave. I asked what troubled his mind.

“' I'm studyin' 'bout gittin' to that blind. We're goin' to the Boss blind and we'll have a tussle to make it with the wind on our quarter. We ought to 'a' gone to the wind'ard further before we anchored."

And we did have a tussle.

We took off half our decoys from the gunning dink and with two ten-foot oars began to shove our craft out over the foaming storm-tossed waters. It was all we could do to stand up against the wind; and with both oars fixed on the bottom, the strength of two men could barely move the fifteen-foot, light cedar boat. It took us an hour to push her three-quarters of a mile to the blind. It was freezing cold, but we were both wet with sweat when we got there.

The Boss blind is a famous one in this bay, 
that stands far out on the mud-flats near the edge of a ship channel. It was first stuck there by Uncle Nathan Cobb, the king of wild fowl hunters in Tidewater Virginia, nicknamed the "Old Boss" by his admirers.

This particular bay has 4,000 acres of mudflats on which the wild celery grass grows, furnishing rich food for the birds. There are many blinds of cedar bushes stuck over its wide sweep, but the old Boss blind is yet the king of them all. It was placed there fifty years ago with consummate skill, in the track of the brant and ducks, and all the ingenuity of rival hunters has never been able to place a blind anywhere in that 4,000 acres to interfere with the flight of birds that pass it in stormy weather.

The tide was just right. It made high water at daylight. This gave us the whole of the ebb tide, the low water and the first movement of the flood tide for shooting. The tides are right for blind shooting on the 
two weeks of full and new moon, and wrong on the two quarters.

As the waters fall off the flats the birds come in to feed on the grass as soon as they can reach bottom with their bills, and, when hungry from a long run of high tides, they come out hours before they can reach bottom in search of shoal places.

We had just put out our decoys as the sun rose, and were pushing into the blind, when a broadbill swept in range before I had loaded a gun.

"They'll come to-day like chickens!" cried George.

"There's a blackduck in the decoys!" I whispered, as he handed me my number ten gun. I bagged him, and then for an hour we were kept busy with the broadbill and blackducks.

At last a flock of brant of about two hundred headed in straight for us. I seized my second gun, loaded with number two shot, and 
made ready. They were flying low in the teeth of the gale. Now I could see their long, black necks and snowy feathers around their legs, and they looked as big as geese. As they drew nearer, with every throat in full cry, the noise sounded like the roar of a fire sweeping a canebrake, exploding the joints of two hundred canes a second! I held my breath, and as they swept in range about thirty yards from the blind, I blazed away, bang! bang! I expected to see it rain brant. I hadn't touched a feather!

"Well, I'll be ——!" exclaimed George.

I had the dry-grins, and looked down at my gun to see if it was really a gun, when I noticed my hands trembling like a leaf.

"Brant fever," was George's dry remark. "You must git over that, if we are to do our duty here to-day."

"I'll maul 'em next time," I promised.

In half an hour another bunch swung in and I brought down three with the first bar- 
rel and two with the second. Then for five hours we had the sport of which I had dreamed.

When the tide had ebbed off and left the flats dry, we counted our game, and we had I 7 brant, I 6 blackducks and Io broadbill, a total of 43 , as fat and toothsome birds as ever tickled the palate of man.

When the tide began to flow back in flood on the flats the wind had died down to a gentle breeze. We took up our decoys, stowed our birds under decks, set our little sail, and as the sun sank in a sea of scarlet glory swept slowly and contentedly back to the Dixie.

It was a red-letter day-one to tell young folks about in the far-away years when one becomes a grandpa and must ask his son for permission to venture out on a stormy day.

Then followed a week of tantalizingly beautiful weather in which the ducks and geese and brant had it all their own way. 
Some days we would get a half dozenoftener two or three. But the glorious moonlit nights, with the chorus of birds chattering and feeding about us, had their compensations of soul peace and dreams.

And then the dinners on board! Of course, salt water gives a man an appetite that balks at few things containing nourishment for the human body, yet it is equally true that one can live as royally on a yacht in Tidewater Virginia as in the palace of a king. And the way my wife cooks brant and ducks and fixes diamond-back terrapin on board a boat is a secret beyond the ken of any hotel kitchen.

This is how she says it is done. The birds are dressed and placed to soak in salt water five hours. Then they are rubbed thoroughly with salt and pepper, and basted about two hours in a very hot stove until so tender you can stick a fork into the breast and turn it easily. 
We are ready now for dinner at 6.30. The saloon is bright and cheerful, and the stove glows with a bed of red-hot coals. We start the music box, and take our places at the four sides of the table. There are four of us-my wife, our two boys, aged fourteen and ten, and myself, but we figure for the needs of eight normal appetites. The first course is fat oysters on the half-shell, picked up by the bushel on the flats at low tide by the cook. The oyster plates give way to diamond-back terrapin stew. We catch our own terrapin. They cost us nothing except the fun of catching them. When I strike terrapin at a banquet in New York I generally have to ask what it is. After the terrapin, the cook sends in the ducksfour browned, juicy, smoking balls on a big game platter! It takes a whole duck for each ravenous appetite-meat so delicious, so tender and toothsome it fairly melts in your mouth! We serve with grape 
jelly, candied sweet potatoes, and steaming hot coffee.

I dream of these dinners the other eleven months of the year. How far away and unimportant the land world seems now! 'We are fifteen miles off shore-fifteen miles from a post-office, telegraph line, or a railroad. We never see a newspaper, know nothing about what is going on in the big, steaming, festering cities, and have ceased to care to know. Our world is now a beautiful bay, fed from the sea by two pulsing tides a day. Only the winds and tides are important. How vain and stupid and unreal seem the vulgar ambitions of men and women who herd in those big iron and stone-bound hives and strive with one another!

It was here that the sense of the pity, the pathos, and the folly of this struggle first stole into my heart, and I ceased to care to be great. I used to think that I was carrying a large part of the world on my shoul- 
ders, and if I dropped it, things would stop with a crash. Here in this mysterious realm of sun and moon and star, wind and tide, bay and sea, sand beach and solemn sweeping marsh, how small and poor that other world, and how little it seemed to need me!

Swiftly the days fly. Ten days go flashing by as a dream, and we rub our eyes in vain effort to account for them.

We waked one morning and found that old Neptune had hauled his wind to the southeast in the night and drawn about us the grey mantle of mystery, a fog. All day long it hung on, dense and clinging, putting out the light of sun, moon, star and friendly lighthouse. The birds never moved a wing or uttered a cry. They huddled in groups wherever the fog caught them. Far out over the sand beach we could hear the deep bay of the ocean hounds crying their distress. It was no use to grumble. We had learned to take things as they came. 
A fog meant a stay indoors: talk and dream and read. From our little library we drew forth our treasures and forgot the fog.

Next morning it was just the same.

"Look out for weather when this clears up," was George's greeting as I walked into the crew's quarters after breakfast.

"What sort of weather?"

"Cold, freezin', goose weather. I see them geese feedin' out there in the sink every day the last week. If this wind hauls into the nor'west to-night, the fog will lift, and we'll talk goose talk in that sink blind in a way that'll make your heart flutter tomorrow."

Next morning it was freezing and the wind was howling a thirty-mile gale from the north.

We went to the goose blind located in the sink, a deep place in the mud-flats that rarely goes dry.

"The wind's just right," said George. 
"Every goose oughter pass this blind today. The wind's blowin' straight across their track, the flocks can't hear our guns, and we can hammer 'em the whole tide."

The goose is the wildest and smartest of all the fowl of our coast and the most difficult to kill. I had shot only four in several years' outing in Virginia, and was crazy for a storm day in their track.

At last it had come. The wind was blowing now a furious gale-so strong were its gusts it was almost impossible to shove out of our blind against it.

The first flock of geese show by their flight the track they will follow for the day. The sound of one gun heard by them will change their plans instantly and cause them to take a new course ten or twelve miles in the opposite direction.

But we had them to-day. The wind was at right angles to their course, and they could 
hear nothing. The first flock came as straight for our blind as an arrow.

What a sight, as they came honk! honk! in long, streaming lines, their necks stretched and their big, ten-foot wings battling with the storm!

Crack! Crack! went four barrels in perfect time, sounding like pop-guns in the howl of the wind, and three big fellows tumbled. When they came swirling down it looked as though we had knocked out a piece of the sky.

We pushed rapidly after them, and yet so terrific was the wind they were swept a hundred yards to the leeward before we could reach them. Then we had a battle royal to get back to the blind. We had barely started shoving with our oars with all the power of every muscle, when a flock of over fifty geese circled over our decoys. And two big flocks followed close on their heels. Hundreds had passed before we got back. 
Suddenly the sky was darkened with such a flock of blackducks as I had never seen at close range. There must have been a thousand of them. They sailed straight in and pitched in our decoys and rolled up in a great black sheet within easy gunshot.

Trembling with excitement, I raised to make the one mighty pot-shot of my life and kill a hundred, when George seized my arm. "Don't shoot. There's a hundred geese comin' right in. Don't fool with blackducks -this is goose day."

I let them alone and killed two geese out of the bunch that came, but I've regretted that lost shot into those blackducks a thousand times since, when they have been tantalizing me on fair days with their insolent display of knowledge.

When the tide had ebbed off at the end of three hours we had seventeen geese that weighed 214 pounds. We hung them up on the big foreboom of the Dixie, George and I 
crouched among them, and one of the boys snapped the camera at us.

It was a day never to be forgotten, and it will be many moons before we see its like again.

It was the harbinger of the greatest freeze Tidewater Virginia ever saw in its three hundred years of English history, and the geese knew it was coming.

Some winters ice does not form at all in these waters. As a rule, it freezes for two or three days in February and then thaws quickly. Sometimes, once in ten years perhaps, the bays will be frozen for a week at a time. But now the mercury suddenly dropped to nine degrees below zero, turning a rainstorm into hail, and freezing our soaked sails as hard as a rock. In three days the bay was frozen solid and the ebb and flow of the tides began to pile the ice against every obstruction in its path. It trimmed our blinds off as smoothly as though a. hig 


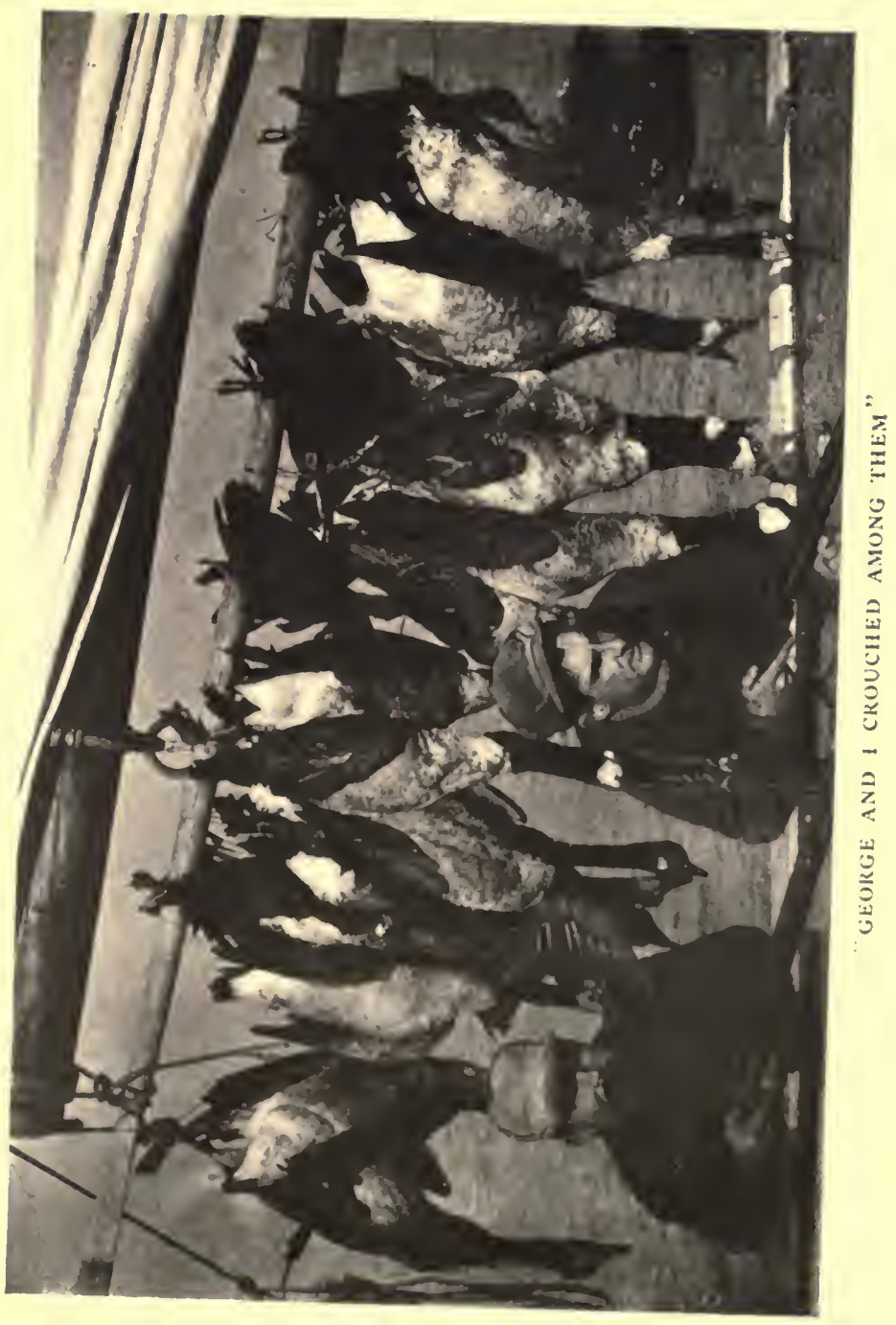



steel razor had done the work, and in four days the bay looked like a picture of the Arctic Occan, and our yacht like a craft caught in the ice in search of the North Pole.

We lifted her big anchors on the catheads and tried to patiently wait for a thaw. Each day we expected a change, but it only grew worse. Two storms had met on the coast and all weather charts were smashed.

The day before this freeze, guests had unexpectedly arrived from New York, and the drain on our pantry had exhausted the supply of fundamentals. At the end of ten days we were out of wood, out of coal, out of oil and short of rations. Then we found that goose bacon is better than Swift's or Armour's.

The whole sweep of Tidewater Virginia was a white desolation of ice; the Chesapeake Bay was frozen eighteen miles from shore to shore; and the ice was packed out sixteen miles into the Atlantic Ocean. 
We had to knock up the small boats, tear the shelving out of the forecastle, and split up our decoys for wood with which to cook two short meals a day. It was fifteen days before the ice field thawed under the Southern sun and rain and began to move out to sea. The rain had at last rotted it enough for our big anchor chain to cut it. So we dropped old "Sleep Easy," and his chain cut the 4,000-acre field in two and it passed harmlessly by.

It was a rough experience, but was worth more than it cost. We had met the ice king clad in his white robes of omnipotent power. We had seen the miracle his breath could work on the face of beautiful waters. In a night he had given to the tide gleaming teeth that could bite an anchor chain in two as though it were a straw. We had seen both anchors on the Dixie's catheads with her sails rolled up. How helpless she looked in this abject surrender! 
Strange noises filled the air. One night the flood tide pushed us out of the channel up on the edge of the high mud-flat. On the ebb the ice began to crowd its tons against the Dixie's upper side. Suddenly it pushed her off the edge of the channel where she had been caught, and when she fell into the deep water her masts quivered like reeds, and the crash rang through her hull like the roar of an earthquake. We were all sound asleep when it happened, but the jump out of bed was unanimous, and the chorus of inquiry had the flavour of Chimmey Fadden's famous remark. We had a laugh all round and went back to sleep.

Of all the sounds I have ever heard a moving ice field, crunching against the sides of a vessel, is the strangest and most thrilling. It comes like the distant, sonorous roar of a storm sweeping down a mountain gorge, and yet it is so close and has such a chorus of intermingled notes that there is absolutely 
nothing like it in nature. The hollow body of the boat becomes the sounding drum of a great musical instrument, and the Spirit of Winter sweeps its strings with trembling, crystal fingers! We sit and listen breathless. No master musician ever composed such music and no orchestra could be found to play it.

The lighthouses, that had been blinking their kindly eyes at us through so many long nights, seemed to have assumed now a strange, glittering stare, and one night, when the storm was at its darkest and wildest pranks, the nearby light was suddenly obscured. Great flocks of geese, brant and ducks, lost and crazed by the storm, were dashing themselves in despair to death against the gleaming lens.

I never cruise in these waters and go home willingly. When the time comes to leave, I feel like a schoolboy driven back to his tasks.

Swiftly a month rolls away. Days seem 


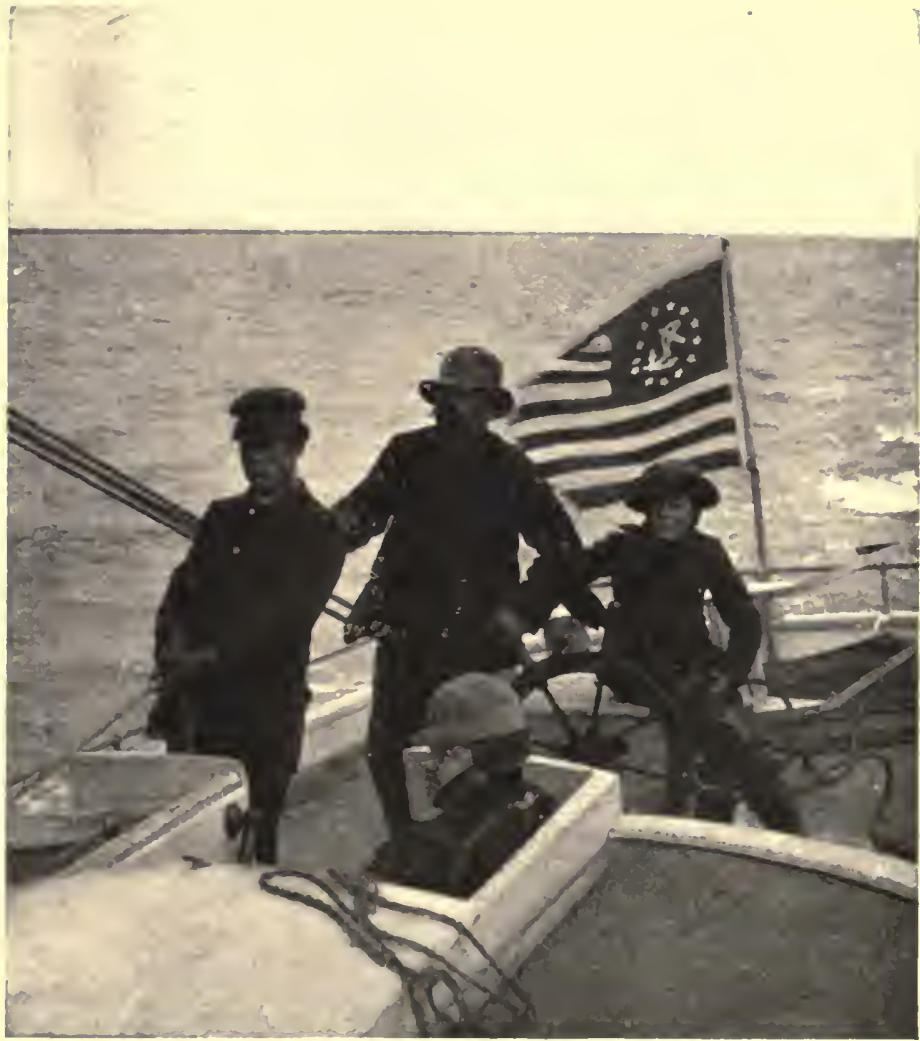

"WE ARE HOMEWARD BOUND NOW, WITH HER BIG YACHT ENSIGN SET AFT AND HER COLOKS AT HER MASTHEAD" 

but hours, and the fatal one dawns, the very last I dare to spend. There are engagements to be met back in that dimly remembered little world where they have mails, telegraph lines, railroads and newspapers. How I hate it all now! I resolve, when I go back, to make a million dollars, sail away and never return except for coal and water.

The order is given to get under way. The boys beg for one more day, but at last give up, begin to swallow lumps in their throats, and fight to keep back the tears. I know my boys do this, because their father and mother do the same thing when they are not looking.

We are homeward bound now, with her big yacht ensign set aft and her colors at her masthead. Every heart is heavy and no one speaks. We feel as though we are sailing away into a strange world. 


\section{CHAPTER XII}

\section{The Frozen Fountain}

All day the wind has been blowing from the north, and dull grey clouds cover the sky.

I awake at home in the morning to find my Southland clothed in the ermine robe of the North-more dazzling in beauty, true; but cold, still, white and deathlike.

The green leaves of the magnolias bend and curve and shrink under their burden, and their satin finger-tips flash with a strange brilliance against the snow's canvas.

The berries of the holly seem groups of tiny altar candles smothered beneath the storm's blanket.

When the first boyish exhilaration passesthe inheritance of childhood's memories -a feeling of sadness creeps over me. The 

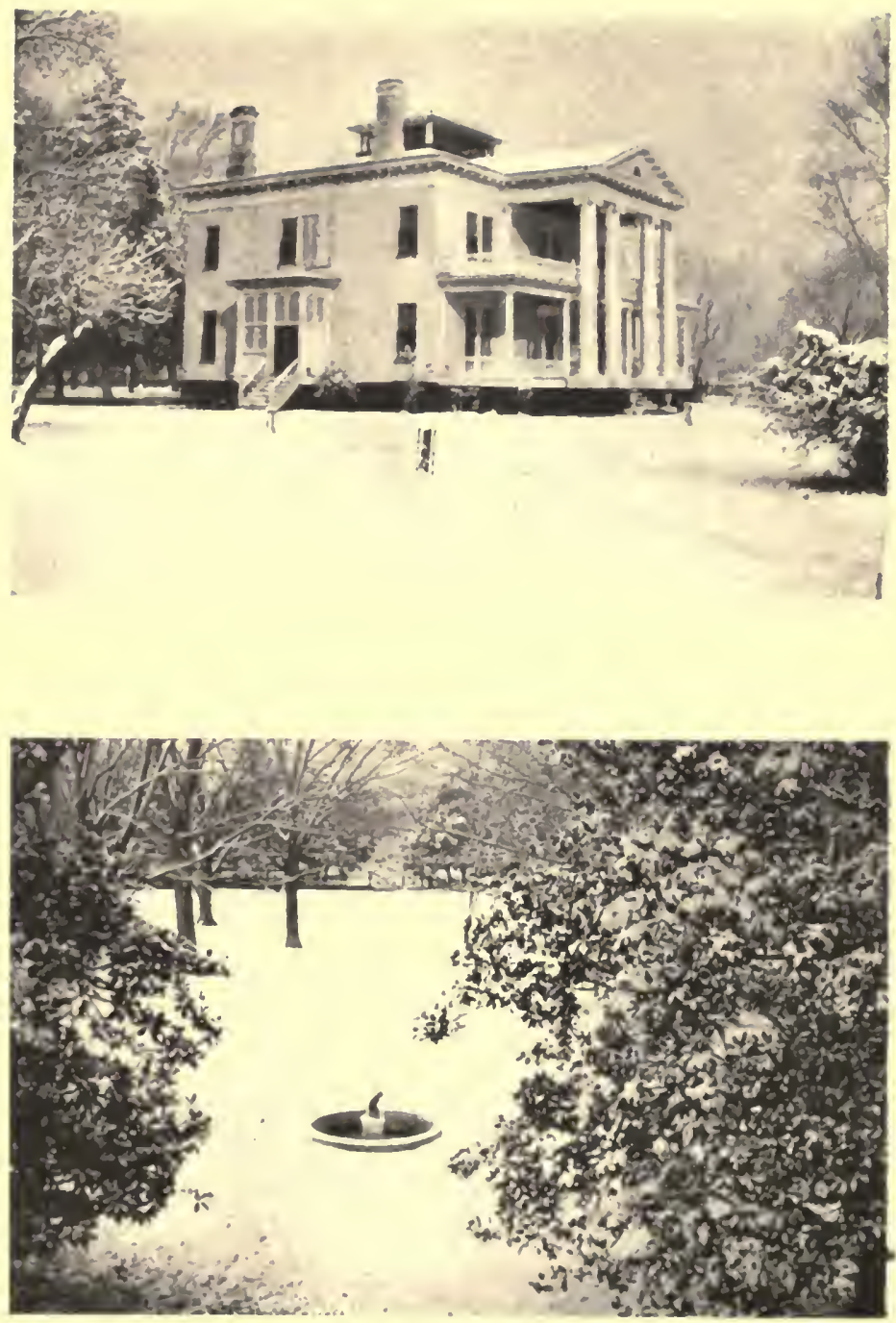

"THE ERMINE ROBE OF THE NORTII" 

house seems immense, and cold, though I feel the warm air pouring through the register and a wood fire roars and crackles in the open fireplace. I am mistaken. The room is not cold, and a greater fear oppresses me. The sense of chill must be in my heart. Even the glow of a wood fire may not reach the soul's hiding-place.

I resolve to take a ride. The sweet breath of the morning, the warmth of my mare's glistening back, the quick beat of her hoof, the pride of her arched neck, and the rhythmic union of my life with hers in the sport we both love-yes, it will warm me. And then I remember that the snow is piled in drifts and my Bess is from the far Southland, a shining child of the sun. Snow is the only thing in all nature's pranks that frightens her. When her footfall comes back muffled, and the packed snow from her shoes begins to strike her breast and flanks, the big, half-human eyes turn and look back 
at me in terror. No, she shall not suffer: I love her-and she cannot understand.

The water is dark in the middle of the river, and I see a widening fringe of ice along the shores. The creek that flows through the lawn is dead and motionless-a flashing sheet of ice. The fountains are still and frozen.

The birds huddle about the door, silent and dazed. I hasten down to grind some corn for them and pour it in heaps in the sheltered places. They find it quickly. The redbirds are first; the larks come in droves and eat as though they are starved; and, last, the mockingbirds and wrens.

I place one pile deep down in the glade behind the garden for the quail I have left to breed two coveys for the next season in the orchard.

I tramp through the snow back to the house, still struggling with a sense of vague uneasiness.

Tired of watching the fire, I go to the 
window and stand for an hour gazing over the freezing waters. My wife is softly playing the piano. Her music has always been a joy to me. Yet, somehow, to-day each sweet note is heavy with tears and their sub-tones begin to stir memories of another life in another world. The wind howls and moans without and sweeps my soul now with desolation.

Yes, there is something the matter with me. Perhaps, after all, I'm not well. Yet my face is bronzed and hardened and every muscle tense as steel. I never felt stronger, and my heart beats with the conscious stroke of new and enormous reserve powers. Perhaps I have come home from hunting too soon. No, I'm just a little tired of hunting. The last quail I shot fluttered pathetically in my hand, and left a tiny blood-mark on my finger. And I thought of it afterwards. I did not enjoy the quail on toast for breakfast quite as well as usual. 
134 The Life Worth Living

As I stand looking down the river in brooding silence, suddenly the Old Dominion steamer sweeps around the bend, the storm spray dashing against her bow, her black and yellow funnel pouring a cloud of smoke into the sky. Her deep bass voice breaks the stillness at the sight of her pier. Three times it rings in triumph over the icy waters, the summons of the big world from whence she comes, where man has built a home beyond the frost line.

I know now, and I begin to pack. I am going back to town. 


\section{CHAPTER XIII}

\section{The City's Lambent Flame}

The old fever is in my blood. I have not lived it down. Why should I strangle the impulse, if God put it within? After all, it is His breath. This longing for fellowship, this consciousness of kinship with the herd is upon me and my heart is beating to its wild music. I lift my head and sniff from afar the dust of their hoofbeat, and my soul answers with a cry.

On the horizon of the night I see the city's lambent flame, the light that never grows dim, the life that never sleeps.

Again I plunge into its human tides and feel the enfolding contagion of their animal and spiritual magnetism. Again I bathe in my favourite pool-the whirlpool at Madi- 
son Square-the vortex into which swift human rivers pour their waters. At this spot, he who has ears can always hear the roar of a Niagara more thrilling than the music of the leap of rivers from granite cliffs.

I see the miles of electric lights flash brighter than the stars, and the glow and splendour and mystery of it all stirs my soul.

Warm hands clasp mine, and the faces of friends smile their greetings.

I hear the music of the orchestra, the tumult and the shout of Broadway on gala nights of grand opera, the voices of my favourites singing as never before-and I am glad.

I slip back into my study hard by the Square-I confess I have always kept it there-and turn up the lights with a sneaking joy at my inconsistency. I hate consistent people, anyhow. 


\section{CHAPTER XIV}

\section{What is Life?}

I have taken it for granted that no life is worth discussion which is not useful; that every life worth the candle is spent in the service of our loved ones and our fellow man, to the end that the world in which we live shall be brighter, wiser, or more beautiful because we have passed through it.

My search is for the highest pathway of this life, and I am convinced that it can only be found in the growth of every power of the soul and the body to the utmost reach of their capacity.

This acme of living cannot be attained in the city. In the city we are spendthrifts. We give, give, give and never receive. I believe that man's full growth will be best 
reached by spending one-third of his time in town and two-thirds in touch with Nature.

To live is to will. To cease to will is to die. He who has ceased to will is dead already-he may fool the undertaker for a while, but he is dead and he ought to be buried.

The gravest charge against the modern city is not merely that its continuous unrest starves the soul, brutalizes the senses, destroys repose, develops insolent and savage impulses-but worse than all this, it murders the will and destroys personality, thus sapping the fountain of life. The collective instincts of the herd-groups in which we move strangle at last the individual, and man becomes but a grain of dust blown hither and thither by the breath of a crowd.

The city's chief crimes are noise and unrest. The human soul cannot grow in an uproar. The crucial moments of history are not found in the hours in which armies 
charge. They are in the still, small voices of the inner life of man. The shriek of shells and the shout of hosts are but their sequence.

Search for the hour of the birth of modern civilization, even in its material aspects, and it will be found in the silence of a lonely room, where a solitary man sat watching the lid of a tea-kettle rise and fall. From that hour flowed the history of a century of progress-the wonders of the age of steam.

These hours of stillness and light are the secret sources of the wealth of life. No man who is without them can live or maintain his sanity.

A Western train on which I was travelling one day suddenly shot forward at breakneck speed. Around dangerous curves we plunged, dashing the passengers from side to side. On past a station we swept, through an excited village, and disappeared in a cloud of dust. No signal to stop was heeded in the engine's cab. At last the conductor crawled 
over the tender, knocked the engineer on the head, grasped the throttle and applied the air brakes. The engineer had gone mad. Leaning far out his window, his hair streaming in the wind, his eyes set on the track, he was muttering unintelligible words.

Only a madman rushes forward without pause. The soul that lives must have hours of silence and repose. 





\section{UNIVERSITY OF CALIFORNIA LIBRARY}

\section{Los Angeles}

This book is DUE on the last date stamped below.

Form L9-15m-10,'48 (B1039) 444 
Dixon-

F'e life worth

livin.

S521

D64 1 
